\title{
ODDZIAŁYWANIE DUSZPASTERSKIE SALEZJANÓW W KOŚCIELE KATOLICKIM NA UKRAINIE
}

\section{Wprowadzenie}

Przedstawiając pokrótce temat: Oddziatywanie duszpasterskie salezjanów w Kościele katolickim na Ukrainie, postaram się przybliżyć zaangażowanie duszpasterskie salezjanów w ich przeszło 100-letniej historii w Europie ŚrodkowoWschodniej, w granicach obecnego państwa Ukrainy, proklamowanego w sierpniu $1991 \mathrm{r}$.

Ks. Jan Bosko (1815-1888), późniejszy święty, opiekun, wychowawca, apostoł i ojciec młodzieży zaniedbanej materialnie i moralnie, zorganizował w 1841 roku. w Turynie Oratorium, formę rozbudowanej świetlicy młodzieżowej. Aby tej pracy zapewnić podstawy organizacyjno-prawne na przyszłość, założył w 1869 roku zgromadzenie zakonne pod nazwą - Towarzystwo św. Franciszka Salezego: populanie salezjanie. Jego celem było i jest wychowanie i kształcenie młodzieży. Salezjanie, na miarę potrzeb i możliwości, podejmują także każdą inną pracę duszpasterską w Kościele ${ }^{1}$.

Ks. Bosko zakładając zgromadzenie zakonne nie planował ograniczać pracy wychowawczej jedynie do własnej ojczyzny. On sam, a nastęnie jego ,duchowi synowie" otwierali placówki nie tylko w państwach kontynentu europejskiego. Śnił ks. Bosko proroczo o misjach w Azji (Hong-Kong, Pekin, Kalkuta), Australii, na Madagaskarze. Jeszcze za swego życia żegnał zakonodawca kolejne grupy salezjanów udających się na misje zamorskie do Ameryki Południowej². Znał sytuację Europy Środkowo-Wschodniej, zdominowanej przez carską Rosję. Bliskie jego sercu było przeszczepienie działalności salezjańskiej na ziemie polskie, skąd salezjanie inicjowali w późniejszym czasie pracę na terenie dzisiejszej Ukrainy.

* Ks. Waldemar Witold Żurek - dr historii Kościoła, adiunkt w Ośrodku Archiwów Bibliotek i Muzeów Kościelnych KUL.

${ }^{1}$ J. B o s k o, Wspomnienia z Oratorium, thum. J. Gutewicz, Warszawa 1987, s. 182-220.

${ }^{2}$ J. B a c c h i a r e 11 o, Sny i wizje św. Jana Bosko Apostoła młodzieży, Warszawa 1989, s. 196-201 . 
W 1898 r. salezjanie zapoczątkowali swoją historię na ziemiach polskich, zniewolonych przez trzech zaborców. Wybrali Oświęcim, gdyż pod zaborem austriackim, w Galicji, mieli stosunkowo najwięcej swobody i możliwości pracy. Do wybuchu pierwszej wojny światowej otworzyli kolejne placówki w Galicji na terenie archidiecezji lwowskiej: w Daszawie (1904), Przemyślu (1907) i Krakowie (1911). Działania wojenne sparaliżowały w dużym stopniu funkcjonowanie tych placówek, zwanych w słownictwie salezjańskim zakładami ${ }^{3}$.

W niepodległej Polsce starania prowincjała salezjanów o zatwierdzenie państwowe Towarzystwa Salezjańskiego zostały pomyślnie zakończone. Ministerstwo Wyznań Religijnych i Oświecenia Publicznego dnia 15 V 1922 r. zatwierdziło Statut Zgromadzenia. Państwowa legalizacja zgromadzenia, pracującego od prawie ćwierć wieku w Polsce, miała dla polskiej prowincji, zwanej u salezjanów inspektorią, pierwszorzędne znaczenie. Inspektoria, uznana za osobę prawną, mogła nabywać, posiadać i rozporządzać dobrami ruchomymi i nieruchomościami. Miało to istotne znaczenie dla organizowania nowych i funkcjonowania dotychczasowych placówek salezjańskich, których do 1933 r. przybyło w Polsce dalszych 20. Dość powiedzieć, że przy szybkim rozwoju dzieł ks. Bosko w Polsce, doszło 16 XII 1933 r. do podziału dotychczasowej inspektorii św. Stanisława Kostki na dwie: północną - św. Stanisława Kostki z siedzibą w Warszawie i południową - św. Jacka Odrowąża z siedzibą w Krakowie ${ }^{4}$.

\section{Salezjanie w Galicji Zachodniej}

Salezjańskie domy zakonne erygowane do roku 1939 w archidiecezji lwowskiej należały do Prowincji św. Jacka.

W marcu 1904 r. salezjanie przybyli do Daszawy k. Stryja i podjęli duszpasterstwo parafialne. Równocześnie erygowano tam nowicjat salezjański. Dwa lata później zorganizowano przy nowicjacie seminaryjne studia filozoficzne. Obok parafii od 1907 r. funkcjonowało w Daszawie Niższe Seminarium Duchowne, które kształciło do października 1939 r. kandydatów do zgromadzenia. Rozpoczęta na wiosnę 1945 r. tzw. repatriacja Polaków z tamtych terenów zakończyła pracę duszpasterską salezjanów w Daszawie ${ }^{5}$.

Następca lwowskiego abpa Józefa Bilczewskiego, abp Bolesław Twardowski, zainicjował budowę wotywnego kościoła pw. Matki Bożej Ostrobramskiej we Lwowie na Górnym Łyczakowie. Wybudowana świątynia miała być symbolem wdzięczności Lwowa i Małopolski Wschodniej za powrót Lwowa do odrodzo-

${ }^{3}$ S. S t y r n a, Zgromadzenie Salezjańskie w Polsce w poszukiwaniu form odpowiedzi na potrzeby wychowawcze $i$ duszpasterskie $w$ latach 1898-1974, w: 75 lat dziatalności salezjanów w Polsce. Księga pamiątkowa, Łódź-Kraków 1974, red. R. Popowski, S. Wilk, M. Lewko, ŁódźKraków 1974, s. 11-12; Z Księdzem Bosko Ojcem i Nauczycielem Młodzieży - po stu latach, opr. M. Dziubiński, Kraków 1998, s. 18-23.

${ }^{4}$ Z Księdzem Bosko Ojcem i Nauczycielem Młodzieży - po stu latach, s. 18-23.

${ }^{5}$ W. Ż u r e k, Salezjańskie szkolnictwo ponadpodstawowe w Polsce 1900-1963. Rozwój i organizacja, Lublin 1996, s. 261. 
nej ojczyzny, po przeszło wiekowej niewoli. W święto Matki Bożej Różańcowej dnia 7 X 1931 r. arcybiskup poświęcił kamień węgielny pod przyszłą świątynię, a trzy lata później w to samo święto - 7 X 1934 r. dokonał jej konsekracji. Pasterz diecezji planował wybudować w pobliżu kościoła zakład rzemieślniczo-naukowy dla ubogiej młodzieży lwowskiej, który miał być „Żywym Pomnikiem” XX-lecia Obrony Lwowa. Stąd realizację tego planu i pracę duszpasterską w kościele Matki Bożej Ostrobramskiej przekazał salezjanom, jako warunek realizacji jego inicjatywy. Wybuch drugiej wojny światowej uniemożliwił wybudowanie zakładu wychowawczo-dydaktycznego dla młodzieży. Do lata 1945 r. kościół MB Ostrobramskiej opuścili wszyscy salezjanie lwowscy, oprócz ks. Józefa Nęcka, prowadzącego duszpasterstwo przy kościele. Pomagał mu ks. Józef Michałek, który przeprowadził się od Sióstr Sacré Coeur na Górny Łyczaków oraz ks. Zygmunt Szelążek. Naukę religii prowadzili przy kościele i w domu sióstr serafitek. Ostatni salezjanie zmuszeni zostali do opuszczenia placówki dnia 4 VI 1946 r. $^{6}$

W 1936 r. salezjanie przejęli drugą placówkę we Lwowie - Zakład Wychowawczy Fundacji Dawida i Antoniny z Suchodolskich Abrahamowiczów, w którym funkcjonowała bursa dla uczniów miejskich szkół powszechnych i średnich. Od 1 IX 1937 r. salezjanie otworzyli przy bursie Prywatne Gimnazjum Męskie. W drugiej połowie października 1939 r. okupacyjne władze radzieckie (a raczej ukraińskie) nakazały salezjanom opuszczenie budynku, do którego nigdy już nie powrócili? .

W lecie 1939 r. salezjanie podjęli kierownictwo olbrzymiego zakładu koedukacyjnego Fundacji hr. Stanisława Skarbka w Drohowyżach k. Mikołajewa, w archidiecezji lwowskiej, gdzie planowali kontynuować działalność wychowawczodydaktyczną. Stosowną umowę podpisano w sierpniu tego roku, a pierwszym przełożonym został ks. Sylwester Król. Mimo wojny rozpoczęto rok szkolny z chłopcami. Wkroczenie Armii Czerwonej i zabiegi miejscowej ludności rusińskiej spowodowały wydalenie - już we wrześniu (październiku) 1939 r. - salezjanów z Drohowyż, którzy wyjechali do Lwowa ${ }^{8}$.

W 1939 r. ówczesny przełożony Zakładu Abrahamowiczów, ks. Józef Michałek, został przeznaczony do zorganizowania nowej placówki w Brodkach, oddalonych o $30 \mathrm{~km}$ od Lwowa. Tamtejszy obiekt (pałac parterowy, park, młyn turbinowy, elektrownia, staw rybny i 50 morgów gruntów ornych) należał do Fundacji im. Abrahamowiczów. Ta placówka planowana była jako filia Zakładu Fundacji Abrahamowiczów, stanowiąc jego zaplecze materialne. Po podpisaniu stosownej umowy dzierżawnej 13 IX 1939 r. salezjanie przystąpili do rozbudowy obiektów z przystosowaniem ich do założonych planów. Wojna 1939 r. zniweczyła tę inicjatywę na zawsze ${ }^{9}$.

${ }^{6}$ S. R o z n e r, W. W. Ż u r e k, Salezjanie we Lwowie w latach 1934-1945, „Archiwa Biblioteki i Muzea Kościelne”, 68 (1997) s. 370-405.

${ }^{7}$ Tamże, s. 419-456.

${ }^{8}$ J. K r a w i e c, Powstanie Towarzystwa św. Franciszka Salezego oraz jego organizacja i dziatalność n ziemiach polskich, Kraków 2004, s. 155.

${ }^{9}$ Ż u r e k, Salezjańskie szkolnictwo ponadpodstawowe w Polsce 1900-1963, s. 144-145. 


\section{Duszpasterstwo salezjanów w Ukraińskiej Socjalistycznej Republice Radzieckiej}

Postanowieniem uczestników konferencji w Jałcie na Krymie dnia 11 II 1945 r. doszło do oderwania od Polski ziem na wschód od linii Grodno-Bug-Przemyśl na rzecz Związku Sowieckiego i zgody aliantów na utworzenie na zasadach moskiewskich Tymczasowego Rządu Jedności Narodowej, ukonstytuowanego dnia 28 VI 1945 r. Konferencja aliantów w Poczdamie (17 VII - 2 VIII 1945 r.) zdecydowała o przyznaniu Polsce Ziem Zachodnich i Północnych z Gdańskiem i części Prus Wschodnich (bez Królewca) oraz na oddanie Związkowi Sowieckiemu ziem polskich na wschód od Niemna, Bugu, Sanu. Ziemie południowo-wschodniej II Rzeczypospolitej zostały wcielone do Ukraińskiej SRR ${ }^{10}$.

Po zmianie wschodniej granicy naszego państwa w 1945 r. salezjanie utracili na wschodzie 11 przedwojennych placówek należących do dwu prowincji polskich. Zdziesiątkowane w czasie II wojny światowej społeczeństwo polskie, w lutym 1945 r. określiło się liczbą 20,5 mln obywateli, przy $5 \mathrm{mln}$ mieszkających poza krajem Polaków. Ci zmuszani byli do skorzystania z łaski tzw. repatriacji i wyjazdu do proklamowanej Polskiej Rzeczypospolitej Ludowej. Wielu Polaków, w tym i kapłanów, było nakłanianych do opuszczenia swoich domostw i placówek duszpasterskich na Kresach Wschodnich poprzez represje, zastraszanie i szantaż. Znaczny procent kresowiaków skorzystała z możliwości wspomnianej repatriacji. Z ogólnej liczby 212 kapłanów-Polaków tylko w arch. wileńskiej (największej diecezji w II Rzeczypospolitej) w 1945 r., w ramach tzw. repatriacji wyjechało 112 kapłanów do PRL-u, w tym i większość salezjanów. Pozostało jednak na Wileńszczyźnie 9 salezjanów, którzy przed wojną i w czasie jej trwania, pracowali w domach salezjańskiej Prowincji św. Stanisława Kostki. Byli to księża: Michał Bulowski, Bronisław Chodanionek, Kazimierz Grzegorczyk, Tadeusz Hoppe, Ryszard Stohandel, Jan Tokarski, Stanisław Toporek, Jan Wielkiewicz i Ludwik Witkowski. Ks. Jan Kapusta, aresztowany 27 IX 1939 r. w Dworcu Nowogródzkim, odbywał karę zsyłki na Syberii i powrócił do Polski 30 XII 1955 r. Jako pracownik fizyczny w kołchozie pracował w Rubnie na Wileńszczyźnie brat zakonny (nazywany u salezjanów koadiutorem) Wojciech Wiertelak. Dopiero po śmierci pozbawionego majątku obszarnika Jana Obsta, u którego mieszkał, powrócił do Polski w 1959 r. Z przedwojennych placówek salezjańskiej Prowincji św. Jacka rozsianych na terenie arch. lwowskiej, nie pozostał żaden salezjanin, który by po II wojnie światowej pracował już w Ukraińskiej SRR ${ }^{11}$.

Największą liczbę placówek utracili salezjanie w 1945 r. w Ukraińskiej SRR 5: Lwów (dwie), Brodki, Daszawa, Drohowyże; następnie w Litewskiej SRR - 4: Wilno (dwie), Kamienny Most, Kurhan; i w Białoruskiej Republice Radzieckiej - 2: Dworzec i Reginów. Najdrastyczniej proces „opuszczania placówek” prze-

${ }^{10}$ W. R o s z k o w s k i, Historia Polski 1914-1996, Warszawa 1997, s. 144-150.

${ }^{11}$ W. W. Ż u r e k, ,Jeńcy na wolności”. Salezjanie na terenach bytego ZSRR po II wojnie światowej, Kraków 1998, s. 9-13. 
biegał w republice ukraińskiej. Dla przykładu przedstawię kościół Matki Boskiej Ostrobramskiej we Lwowie na Górnym Łyczakowie ${ }^{12}$.

Kilka dni przed wyznaczoną na 4 VI 1946 r. datą tzw. repatriacji salezjanów z Górnego Łyczakowa (trzeci transport) przybyli odpowiedni urzędnicy dokonać inwentaryzacji kościoła i zajmowanych mieszkań. W ostatnią niedzielę odprawiono w kościele sumę jako Mszę św. zbiorową w intencji wszystkich mieszkańców Górnego Łyczakowa, zarówno wyjeżdżających jak i tych, którzy pozostawali. Na dzień następny, poniedziałek, zapowiedziano ostatnie nabożeństwo i odniesienie kluczy do Izby Skarbowej. To nabożeństwo tak opisał główny obserwator tamtych wydarzeń i miejscowy proboszcz - ks. Józef Nęcek:

Od wczesnego rana paliły się w kościele wszystkie świece, lampy, zacheuszki. Wystawienie Najświętszego Sakramentu trwało od 6 rano. Odprawili Mszę św.: ksiądz Szelążek, ksiądz Michałek i ja ostatnią. Rozdałem Komunię świętą i wypuryfikowałem naczynia liturgiczne. Po nabożeństwie Hostię z monstrancji spożyła siostra Elżbietanka. Ludzie nie chcieli rozstawać się ze swą ukochaną świątynią. Wstrząsająca była chwila, gdy mistrz murarski, staruszek 80-letni, który 10 lat przedtem wmurowywał Relikwie święte do ołtarza, teraz donośnie uderzył młotem, ażeby Relikwie wyjąć [...] Nie szło łatwo, bo ołtarz z jednolitego kamienia [...] po całym kościele rozlegał się łomot młota i szloch wiernych, którzy całowali mury kościoła, ołtarze, żegnali się z pochowanym tam arcybiskupem, a potem z nami. Posługi religijne katolików lwowskich miał spełniać odtąd jedynie kościół katedralny ${ }^{13}$.

Salezjanie, którzy po wojnie pozostali poza granicami ówczesnego państwa polskiego, skupili się w przedwojennych placówkach lub okolicy na terenie republiki litewskiej i białoruskiej. Z biegiem lat warunki zewnętrzne i potrzeby wiernych sprawiły, że rozproszyli się po terytorium republik Związku Sowieckiego. Do Białoruskiej SRR udali się księża: Ludwik Bulowski, Kazimierz Grzegorczyk, Jan Tokarski, Jan Wielkiewicz, Ludwik Witkowski. Do Mołdawskiej SRR wyjechał w 1949 r. ks. Bronisław Chodanionek. Do dalekiej Odessy nad Morzem Czarnym w Ukraińskiej SRR udał się w grudniu 1958 r. ks. Tadeusz Hoppe. Ks. Ryszard Stohandel w 1959 r. powrócił do Polski. Ks. Stanisław Toporek zmarł w 1977 r. jako proboszcz w Ławaryszkach k. Wilna i pochowany został obok tamtejszego kościoła parafialnego pw. św. Jana Chrzciciela ${ }^{14}$.

Po 1945 r. w Związku Sowieckim rozproszeniu uległy zakony a ich członkowie zmuszani byli do zerwania łączności z przełożonymi. Miało to prowadzić do zerwania $\mathrm{z}$ własnym zgromadzeniem czy zakonem. W tej sytuacji zakonnicy podejmowali pracę duszpasterską, a siostry zakonne po zdjęciu habitów pracowały zawodowo, prowadząc w podziemiu wspólnotowe życie zakonne. W owym

${ }^{12}$ Świątynia wybudowana jako wotum wdzięczności za opiekę nad miastem w okresie walk w latach 1918-1920 i powrót Lwowa do Macierzy. Wzniesiona (1931-1934) na wzgórzu koło Parku Łyczakowskiego z inicjatywy arcybiskupa Bolesława Twardowskiego, według projektu prof. Tadeusza Obmińskiego. Z woli arcybiskupa duszpasterstwo w kościele przejęli w 1934 r. salezjanie. J. Tokarski, Ilustrowany przewodnik po zabytkach kultury na Ukrainie, t. 1, Warszawa 2000, s. 95.

${ }^{13} \mathrm{R}$ o z n e r, Ż u r e k, Salezjanie we Lwowie, s. 404-405.

${ }^{14} \dot{Z}$ u r e k, ,Jeńcy na wolności”, s. 11-13. 
czasie kapłani zakonni traktowani byli przez władze komunistyczne jako kler diecezjalny ${ }^{15}$.

Salezjaninem, który w tamtym czasie zdecydowanie podkreślał swą przynależność do salezjanów, był ks. Tadeusz Hoppe.

Po święceniach kapłańskich otrzymanych 24 I 1943 r. w Wilnie z rąk bpa Mieczysława Reinysa, ks. Hoppe pracował na Wileńszczyźnie: przy kościele Opatrzności Bożej w Wilnie (1943), w Rudnikach, Porudomino i Jaszunach (1943-1947), Solecznikach Wielkich (1947-1949), Kalwarii Wileńskiej (19491954) i Ławaryszkach (1954-1958) ${ }^{16}$.

Odpowiadając na prośbę bpa Julijonasa Stiepanowičiusa, w jesieni 1958 r. ks. Hoppe zdecydował się pojechać do dalekiej Odessy nad Morze Czarne, obwodowego miasta Ukraińskiej Socjalistycznej Republice Radzieckiej, w diecezji tyraspolskiej, by objąć kościół pw. św. Piotra, tzw. pofrancuski ${ }^{17}$. Wyjeżdżał legalnie, za pozwoleniem władz kościelnych i państwowych. Już na drugi dzień po przybyciu -8 grudnia tego roku - oznajmił odeskim wiernym, iż będzie tu pracował do swojej śmierci. Słowa dotrzymał. Zmarł 10 XI 2003 r. w Odessie, po 45 latach pracy duszpasterskiej dla tamtejszych katolików. Pochowany został na odeskim cmentarzu katolickim, w „ogrodzie kapłańskim”, wśród mogił kapłanów, którzy tam zostali pochowani od $1885 \mathrm{r}$.

Dla obserwatora wnikliwie badającego życie i działalność duszpasterską ks. Hoppe zastanawiające jest, dlaczego odszedł z Ławaryszek i wyjechał na Ukrainę? Pracując na terenie Litewskiej Republiki Radzieckiej pozostawiał po sobie w parafiach opinię proboszcza i duszpasterza zaangażowanego w życie parafii i zainteresowanego dobrem duchowym, i nie tylko, wiernych.

Ks. Bronisław Kant, salezjanin, twierdzi, że ks. Hoppe miał nieustanne problemy z władzami. Przyczyn było wystarczająco wiele: odważne kazania, praca z ministrantami, sprawa noszenia medalików przez uczniów szkolnych, praca z młodzieżą. Za taką pracę spotykały duchownych szykany, z więzieniem włącznie. Wówczas pełnomocnik ds. religii w Wilnie kilkakrotnie polecał ks. Tadeuszowi, aby wyjechał do Odessy. Ten odmawiał, tłumacząc się brakiem zgody biskupa. „Albo jedziesz dobrowolnie do Odessy, albo odbieram ci kartę rejestracyjną (tzw. sprawkę) i nie będziesz mógł w żadnym kościele na terenie Związku Radzieckiego spełniać funkcji kapłańskich. Wybieraj” - rozkazywał urzędnik. W takich okolicznościach ks. Hoppe „przyjął” propozycję wyjazdu nad Morze Czarne - kończy ks. Kant ${ }^{18}$.

15 Jeszcze w 1990 r. na Ukrainie nie wolno było zakonnikom i siostrom zakonnym zakładać własnych habitów. Zob. P. W y s z k o w s k i, Moc wiary. Próba przedstawienia prześladowań Kościoła rzymskokatolickiego na Ukrainie na przykładzie parafii Św. Anny w Barze w latach 1917-1991, Poznań 1998, s. 45-48.

${ }^{16}$ Ż u r e k, , Jeńcy na wolności”, s. 77-94.

${ }^{17}$ Kościół pw. św. Piotra zbudowany został w 1913 r. głównie dla francuskich katolików. Zamknięty przez władze sowieckie, odzyskany w 1947 r. staraniem tamtejszych wiernych. Służył dla katolików 15 narodowości i był jedynym czynnym kościołem katolickim we wschodniej części Ukraińskiej SRR po II wojnie światowej.

${ }^{18}$ B. K a n t, Będziesz jak władyka, na pół Ukrainy, „Misje Salezjańskie”, 6 (2003) (97) listo- 
Większość nie wierzyła $\mathrm{w}$ to, że ks. Tadeusz będzie mógł dłużej pracować w Odessie. Nawet wspomniany wyżej pełnomocnik ds. religii polecił biskupowi Stiepanowičiusowi, by na opróżnione probostwo w Ławaryszkach przez pół roku nie wyznaczał następcy, gdyż pewny był, że ks. Hoppe na pewno wróci; z własnego wyboru lub z konieczności. Administratorem po ks. Tadeuszu w Ławaryszkach został tamtejszy rezydent, ks. Antoni Rukas, a dopiero w marcu 1959 r. ks. Antoni Dziekan otrzymał nominację na proboszcza.

Po przyjeździe na nowe miejsce pracy zainteresowany winien postarać się o „sprawkę”, dokument władz państwowych na sprawowanie czynności kapłańskich i duszpasterskich na określonym terenie. Takie starania poczynił ks. Hoppe na miejscu. Z Odessy został skierowany do pełnomocnika ds. kultu w Kijowie. Tam w czasie rozmowy ks. Hoppe dowiedział się, że urzędnik pochodził ze Lwowa, a w czasie II wojny światowej był żołnierzem Armii Czerwonej. W czasie zwycięskiej ofensywy na Berlin został ranny w okolicach rodzinnych ks. Hoppe w Poznańskim. Rozpoznanie u niego oznak życia przez chłopów zwożących ciała zabitych, po stoczonej bitwie pod eskortą niemiecką i zsunięcie go w odpowiednim momencie do rowu w lesie, uratowało mu życie. W rozmowie z księdzem urzędnik wyrażał wdzięczność za okazaną przysługę, pochwalał chłopów wielkopolskich słowami, że: „tamtejsi ludzie są dobrzy”. W zamian za to otrzymał ks. Hoppe ustne zapewnienie pełnomocnika, że on nie będzie mu utrudniał wykonywania obowiązków duszpasterskich, a w razie potrzeby może w każdej sprawie przyjeżdżać do niego do Kijowa, ubrany w sutannę. Domyślał się już wówczas proboszcz odeski, że może liczyć w przyszłości na jego „pomoc”, a otrzymawszy „sprawkę" mógł podjąć pracę duszpasterską ${ }^{19}$.

Kościół św. Piotra w Odessie był mocno zaniedbany. Ks. Hoppe dokonał w nim koniecznych prac renowacyjnych. Prokatedra pw. Wniebowzięcia NMP pozostawała zamknięta od 1949 r. Zamieniona została na obiekt sportowy. Zasięg parafii odeskiej obejmował miasto i cztery województwa: Cherson, Dniepropietrowsk, Mikołajów i Kijów.

Przez 7,5 roku ks. Hoppe dojeżdżał każdego miesiąca do Kijowa, gdzie władze zezwoliły na zarejestrowanie „Domu modlitwy”, który stał się zaczątkiem ośrodka duszpasterskiego. Na stałe w Kijowie osiadł w 1980 r. ks. Jan Krapan (ur. 1932) z Rygi. Obecnie duszpasterzują tam Ojcowie Karmelici.

Po śmierci ks. Bronisława Chodanionka ${ }^{20}$ w Kiszyniowie († 25 XI 1973 r.) dojeżdżał także i do stolicy Mołdawskiej SRR. Wyjeżdżał z Odessy nocnym pociągiem, by móc od rana służyć tamtejszym wiernym. W momencie przybycia do

pad-grudzień, s. 7-8.

${ }^{19}$ Ż u r e k, „Jeńcy na wolności”, s. 96.

${ }^{20}$ Ks. Chodanionek (1910-1973), salezjanin urodzony w parafii Hermanowicze na Wileńszczyźnie. Święcenia kapłańskie otrzymał 8 XI 1941 r. w Wilnie. Pracował w parafii Vytanei (Witany) i Saldutiškis (Saldutiszkach) na Litwie. Po wojnie w parafiach na terenie Litewskiej SRR: Ejszyszki i Porodomino. W 1949 r. wyjechał do pracy w Kiszyniowie w Mołdawskiej SRR. Obsługiwał także punkty duszpasterskie rozsiane na terenie republiki. Tam pracował do śmierci 25 XI 1973 r. Ż u r e k, ,Jeńcy na wolności”, s. 33-72. 
Kiszyniowa w 1974 r. neoprezbitera, ks. Władysława Zawalniuka ${ }^{21}$, ks. Hoppe urządził mu prymicje i wprowadził w tamtejsze duszpasterstwo.

W Odessie ks. Hoppe zjednał sobie wiernych. Uważał się za pokorne narzędzie w ręku Boga. Sposób jego bycia i odnoszenia może dziwił przy pierwszym kontakcie. Do tzw. stylu lub „liturgii hoppiańskiej” wierni się przyzwyczaili, od początku w niej wzrastali, była dla nich czymś oczywistym i nie raziła.

Jakie miał możliwości i do jakich form pracy uciekał się ks. Hoppe w swojej działalności duszpasterskiej?

W czasach komunistycznych nie było możliwości drukowania książek religijnych, książeczek do nabożeństwa i modlitewników. Ks. Hoppe zainicjował książeczki „od ręki”. Wierni pisali modlitwy i pieśni ręcznie na kartkach papieru małego formatu, następnie poszczególne części zszywali razem i tak powstawały książeczki do nabożeństwa. Pieśni przepisywane do powstających modlitewników miały jeszcze tzw. dodatek odeski, a więc zwrotki lokalnego autorstwa ${ }^{22}$.

Chrztu udzielał w świątyni. Nierzadko ludzie na stanowiskach zapraszali go do swoich domów, gdzie ich dzieciom i wnukom udzielał chrztu św.

Jeśli umarł ktoś na prowincji i nie wiadomo było czy i kiedy ostatni raz przystąpił do sakramentów świętych, a pogrzeb z wiadomych względów - brak pozwolenia władz - odbywał się bez udziału kapłana, proboszcz przez zaufaną osobę posyłał w pudełku po zapałkach odrobinę poświęconej ziemi. Jej wsypanie do grobu zastępowało formę jego poświęcenia przez kapłana. Były przypadki, że poświęconą ziemię posyłał listem pocztowym. Miejscowi wierni z Odessy przynosili także księdzu ziemię do poświęcenia, którą następnie posypywali groby bliskich. Rodziny zmarłych prosiły księdza, w przypadku pogrzebu krewnego, aby wcześniej ks. Hoppe prywatnie odprawił liturgię pogrzebową, przed pogrzebowym ceremoniałem państwowym. W ostatni poniedziałek miesiąca odprawiana była w kościele Msza św. za zmarłych w minionym miesiącu, przy katafalku i świecach, a po Soborze Watykańskim II bez katafalku, ale z odpowiednią dekoracją na środku kościoła.

Proboszcz zabiegał, aby parafianie spowiadali się często. Spowiedź pierwszopiątkowa i z okazji świąt kościelnych przeciągała się do późnych godzin wieczornych (23.00). Przed Mszą św. poranną i wieczorną był do dyspozycji w konfesjonale godzinę wcześniej i nie rozpoczynał liturgii mszalnej o wyznaczonej godzinie, zanim nie wyspowiadał ostatniego penitenta. W niedziele spowiadał tylko przyjezdnych. Miejscowym parafianom przypominał: „macie się spowiadać w inne dni", aby w ten sposób umożliwić skorzystanie z sakramentu pokuty dla przybyłych spoza miasta. Była to praktyka niespotykana, ale zasadna z racji duszpasterskich ${ }^{23}$.

${ }^{21}$ Ks. Zawalniuk, s. Mateusza, ur. 8 VI 1949 r. w Murafie (diec. kamieniecka), wyświęcony na kapłana 26 V 1974 r. w Rydze, pracował w Kiszyniowie, od 1991 proboszcz kościoła pw. św. Szymona i Heleny w Mińsku, stolicy Białorusi, zamkniętego w 1937 r., a zwrócony do kultu w 1990 roku.

${ }^{22}$ W. W. Ż u r e k, Działalność duszpasterska ks. Tadeusza Hoppe w Odessie, w: Polacy na Krymie, red. E. Walewander, Lublin 2004, s. 220-225.

${ }^{23}$ Ks. Ryndzionek do ks. Żurka z 14 XI 2005 r. - Korostyszew (zb. aut.). 
Gdy penitent przystąpił do spowiedzi i przyjął Komunię św., a następnie przez kilka dni był nieobecny w kościele i po ponownym przyjściu pragnął przyjąć Najświętszy Sakrament, wcześniej winien się wyspowiadać. Ks. Tadeusz wyjaśniał, że człowiek jest grzeszny i nie może żyć bez grzechu dłużej jak 2-3 dni. Pierwszy czwartek, piątek i sobota miesiąca były to dni szczególne. Wszyscy niejako „mieli obowiązek” przystąpić do spowiedzi i Komunii św. Chorym parafianom Komunię św. przynosiły w ciągu miesiąca zaufane osoby. Natomiast z okazji pierwszego piątku proboszcz udawał się osobiście do chorych z Komunią św. i spowiadał ich wcześniej.

Nie zaniedbywał biednych, samotnych i chorych, którzy oczekiwali pomocy materialnej. Parafianka Sabina Pilecka udawała się do takich osób, gotowała im posiłki, karmiła, robiła konieczne zakupy. Przy tej okazji przynosiła od księdza proboszcza potrzebującym pomoc finansową. Nazywana była przez nich „Aniołem Stróżem chorych”. Zmarła w styczniu 1997 r. ${ }^{24}$

Kobiety miały obowiązek przystępować do Komunii św. z nakrytą głową. Dziękczynienie odprawiano wspólnie. Polegało ono na odmówieniu kilku modlitw dziękczynnych przez wszystkich chóralnie.

Jak w każdym kościele katolickim, odprawiał nabożeństwa liturgiczne. W maju przed Mszą św. wieczorną nabożeństwo majowe z litanią loretańską, czytanką, modlitwą św. Bernarda, a wszystko przeplatane pieśniami maryjnymi.

W czerwcu, o tej samej porze, odprawiał nabożeństwo czerwcowe do Najświętszego Serca Pana Jezusa z litanią i błogosławieństwem Najświętszym Sakramentem.

W lipcu odprawiano nabożeństwo do Krwi Przenajdroższej z litanią do Krwi Pana Jezusa.

W październiku nabożeństwo różańcowe z różańcem do Matki Bożej, litanią loretańską, pieśniami maryjnymi i błogosławieństwem Najświętszym Sakramentem.

W listopadzie wczesnym popołudniem nabożeństwo żałobne na cmentarzu katolickim, a wieczorem nabożeństwo liturgiczne z wypominkami i różańcem do Matki Bożej.

Za czasów chruszczowowskich przyjechał do Odessy i zamieszkał u „przyszywanej" ciotki ks. Władysław Mikulewicz ${ }^{25}$, salezjanin. Planował osiedlenie się tam jeśli nie na stałe, to przynajmniej na dłużej. Ks. Antoni Chomicki, proboszcz z Murafy, zaopatrywał go w wino i hostie do odprawiania Mszy św. Władze wyśledziły go. „Namierzył” go także ks. Hoppe, który dwukrotnie spotkał się potajemnie z ks. Mikulewiczem. Wówczas usłyszał ks. Tadeusz od przybysza, by się nim nie interesował, a tym bardziej nie obawiał jako „konkurenta”, gdyż on pragnie działać na własną rękę, by nikomu nie przysparzać kłopotów ze strony władz komunistycznych. Ks. Mikulewicz pozostawał w Odessie dwa lata z przerwami.

${ }^{24}$ Relacja Miry Parchomiuk z 10 IX 2003 r. - Odessa (zb. aut.).

${ }^{25}$ Ks. Mikulewicz, ur. na Wileńszczyźnie, przyjechał do Polski w ramach ostatniej repatriacji pod koniec lat 50. ubiegłego stulecia. Po święceniach kapłańskich pracował w duszpasterstwie parafialnym w placówkach salezjańskich w Polsce i na misjach w Afryce. Od kilkunastu lat pracuje w Wilnie. 
W tym czasie cztery razy wyjeżdżał i wracał. W końcu został aresztowany w 1971 r. Po przesłuchaniu, w eskorcie dwóch milicjantów, został odesłany do Brześcia nad Bugiem i przekazany polskim pogranicznikom. W Odessie ks. Mikulewicz przeszedł epidemię cholery. O oznaczonej godzinie na dźwięk alarmu wszyscy przyjmowali leki. Na plaży odeskiej zebrano piasek do $20 \mathrm{~cm}$. W czasie przesłuchania, na którym zapadła decyzja o wydaleniu ks. Mikulewicza z Odessy do Polski, ten powiedział: „Cholera mnie nie wypędziła z Odessy, a wy mnie wypędzacie". Przesłuchujący go generał doradził mu, aby się ożenił, a wówczas otrzyma obywatelstwo sowieckie ${ }^{26}$.

Pod koniec lat osiemdziesiątych ubiegłego stulecia salezjanie południowej Prowincji św. Jacka wyjeżdżali na zaproszenie „turystycznie” do Odessy, by pomagać ks. Hoppe w duszpasterstwie. Do nich należał ks. Kazimierz Szydełko, ks. Piotr Solich, ks. Stanisław Żak, ks. Joachim Jasita. Niektórym z nich udało się zatrzymać dłużej, a ks. Jasita pracuje tam do dnia dzisiejszego.

Pierwsi salezjanie wyjeżdżający do pomocy w duszpasterstwie księdzu Hoppe w Odessie, z różnych powodów, nie zatrzymali się tam na dłużej. Z Odessy ksiądz prałat pisał rozpaczliwe listy, bombardował telegramami przełożonych swoich, że kościół katedralny w Odessie będą oddawać. W 1990 r. ks. Ignacy Ryndzionek ${ }^{27}$ skierował kolejną prośbę do Rady Inspektorialnej w Krakowie o wyjazd do Odessy. Jako pracownik poligrafii w Inspektoracie Salezjańskim w Krakowie przy ul. Konfederackiej 6, gdzie do pracy wydawniczej instalowano komputery z odpowiednimi programami, dotychczasowy pracownik o umiejętnościach plastycznych czuł się ,niepotrzebny”. Petent otrzymał zgodę na wyjazd. Po przybyciu do Odessy ks. Ryndzionek zamieszkał z prałatem w mieszkaniu pod kościołem św. Piotra. Jako wikariusz otrzymał od proboszcza polecenie organizowania ludzi W sprawie przejęcia kościoła katedralnego ${ }^{28}$.

W momencie przybycia ks. Hoppe do Odessy tamtejsza prokatedra pw. Wniebowzięcia NMP od dziewięciu lat pozostawała zamknięta. Po raz pierwszy zamknęły ją władze sowieckie w 1936 r. na skutek prześladowań Kościoła rozpoczętych w ZSRR w 1935 r. Wówczas została ograbiona z najcenniejszych przedmiotów kultu i obrazów. Jej otwarcie nastąpiło w 1941 r. Już w 1949 r. ponownie

\footnotetext{
${ }^{26}$ Relacja ks. Władysława Mikulewicza z 10 IX 2003 r.- Odessa (zb. aut.).

${ }^{27}$ Ks. Ryndzionek, s. Stanisława i Władysławy z Miłaszewiczów. Ur. 30 VII 1932 r. w Leonpolu na Wileńszczyźnie, nad samą granicą sowiecką, obecnie diecezja witebska na Białorusi. W 1945 r. rodzina Ryndzionków wyjechała z Związku Sowieckiego do Polski, ratując się przed wywózką na Sybir. Syn Ignacy wstąpił do salezjanów. Nowicjat odprawił w Kopcu, gdzie złożył profesję zakonną dnia 5 VIII 1951 r. Święcenia kapłańskie otrzymał 20 VI 1959 r. w Oświęcimiu. Po święceniach pracował w placówkach salezjańskich. W 1972 r. otwarła się dla ks. Ryndzionka granica na wschód. Odwiedził dom rodzinny na Wileńszczyźnie. Mszę św. odprawiał tam prywatnie w domu. Czasami odprawiał w kościele ale przy drzwiach zamkniętych. Dopiero przyjeżdżając w następnych latach stopniowo mógł odprawiać jawnie dla wiernych. Już w latach 80. ubiegłego stulecia zdarzyło mu się wyspowiadać niemal całą parafię w Miorach. Wówczas pomyślał: trzeba jechać z kapłaństwem na wschód. To marzenie zaczął realizować od 1992 r. wyjazdem do pracy na Ukrainie. L. K a 1 i ń s k i, Rodzina Salezjańska w Polsce. Wykaz domów i osób, Warszawa 1988, s. 105.

${ }^{28}$ Ks. I. Ryndzionek do ks. W. Żurka z 14 XI 2005 r. - Korostyszew (zb. aut.)
} 
zamknęli ją komuniści na dziesiątki lat. Świątynia została przebudowana do celów sportowych. Jednak parafianie i ks. prałat Tadeusz Hoppe nie zapomnieli o niej. Ich wspólna modlitwa i zaangażowanie sprawiły, że dnia 9 VIII 1991 r. nastąpił szczególny dzień i znak Opatrzności Bożej - prokatedra pw. Wniebowzięcia NMP powróciła do właściwych gospodarzy, a wierni wspólnie z swoim duszpasterzami odśpiewali wielkanocny hymn: Wesoły nam dziś dzień nastat. Dnia 11 sierpnia tego roku w drzwiach głównych katedry odprawił ks. Hoppe Mszę św. z tamtejszymi salezjanami, przewodnicząc w koncelebrze ${ }^{29}$.

Tamtejsza społeczność katolicka jest w większości polska. Stąd trud odbudowy byłego pałacu sportu podjęli Polacy, na czele z ks. Ignacym Ryndzionkiem, który zamieszkał teraz nad dawną zakrystią oddanej świątyni. Rozpoczęły się zakrojone na szeroką skalę prace remontowo-budowlane i służba Boża. Ksiądz Ignacy kierował remontem świątyni, prowadząc równocześnie duszpasterstwo wiernych. Kołatał do serc ludzkich i instytucji w Polsce i za granicą, aby zgromadzić potrzebne środki na odbudowę kościoła ${ }^{30}$.

Skoro tylko wyremontowano podziemia w katedrze (1992-1993), powstała tam kaplica. Schodzono do niej na celebrę, gdy w samym kościele były intensywne prace albo mróz siarczysty. Tam ,zadomowili” się grekokatolicy i sprawują liturgię w święta i dni powszednie.

Odessa to wielki port morski przyjmujący do 3.000 statków rocznie. Tutejsi salezjanie udzielali się odprawiając Służbę Bożą na statkach, uczestniczyli w ekumenicznych nabożeństwach. Wspólnie z prawosławnymi święcili wianki, każdy w swoim obrządku, ale kropili je z jednej kropielnicy. Wodę święconą z naszego kościoła - wspomina ks. Ryndzionek - zabierali także bracia prawosławni. Oprócz odeskich parafii funkcjonowały także kaplice w mieście portowym: Illiczowsk, Jużnyj, Kominternowskoje.

W 1994 r. nastąpił podział jedynej dotychczasowej parafii odeskiej z kościołem św. Piotra. Utworzono kolejne dwie parafie: św. Aleksandra prowadzoną przez Księży Pallotynów, i katedralną Wniebowzięcia NMP z proboszczem ks. Ryndzionkiem. W pracy duszpasterskiej pomagali ks. Ryndzionkowi kolejni współbracia: ks. Joachim Jasita, przybyły do Odessy w 1992 r. oraz tamtejszy rodak, ks. Vitalij Krzyvicki, wyświęcony w 1997 r. w Krakowie. Kolejnym wikariuszem w parafii został w 2001 r. neoprezbiter, ks. Marian Kuc ${ }^{31}$, który w parafii pracował dwa lata. Następnie w latach 2003-2005 pracował w Centrum Młodzieżowym przy ul. Malinowskiego w Odessie. Kilkakrotnie przyjeżdżał do Odessy ks. Stanisław Żak, pracujący wówczas w Moskwie. Władze po pewnym czasie nakazywały mu wyjazd. Wreszcie przybył do Odessy w 1998 r. bodaj po

${ }^{29}$ F. D z i c z k i e w i c z, A. A d a m k o w s k i, Odzyskana katedra, „Królowa Apostołów”, LCI (1992) nr 12 (130), s. 15.

${ }^{30}$ Ks. Ignacy Ryndzionek do ks. Żurka z 14 XI 2005 r. - Korostyszew (zb. aut.).

${ }^{31}$ Ks. Kuc, ur. 1 VIII 1973 r. we Lwowie, nowicjat salezjański 1992/1993 w Kopcu k. Częstochowy, studia filozoficzne 1993-1995 w Krakowie, praktyka pedagogiczna 1995/1996 w Korostyszewie i kolejny rok 1996/1997 w Zakładzie im. Ks. Bosko w Oświęcimiu, teologia 1997-2001 w Krakowie, święcenia kapłańskie dn. 16 VI 2001 r. we Lwowie z rąk kard. Mariana Jaworskiego. Relacja ks. M. Kuca z 20 II 2006 r. - Przemyślany (zb. aut.). 
raz trzeci. Jak zawsze pomagał w duszpasterstwie przy kościele św. Piotra. Ten przyjazd, na zaproszenie ks. Hoppe, został wcześniej „,przygotowany” na odpowiednim szczeblu. Podjęte starania zaowocowały. Ks. Stanisław otrzymał tymczasowe zameldowanie na pół roku, po upływie którego miał dostać kartę czasowego pobytu w mieście. Kwietniowego poranka 1999 r. ks. Stanisław nie przybył do konfesjonału, podczas gdy ks. prałat odprawiał Mszę św. Po skończonej Eucharystii ks. Hoppe udał się do pokoju wikariusza, zastał go leżącego w łóżku - zmarłego, a planował naznaczyć go swoim następcą na probostwie.

Obraz z głównego ołtarza prokatedry maryjnej zachował się w kościele św. Piotra. W lecie 2003 r. został poddany konserwacji, a dnia 25 sierpnia tego roku odbyło się jego uroczyste przeniesienie do odnowionej katedry przy ul. Ekatierinienskoj. Procesja z obrazem prowadzona przez biskupa odesko-symferopolskiego, ks. Bronisława Bernackiego, podążała ulicami miasta. Księdza prałata wieziono samochodem $\mathrm{W}$ czasie procesji spoglądając na niesiony obraz, opłakiwał swój los mówiąc: „Za obrazem odejdę i ja”. Te słowa miały się spełnić za kilkadziesiąt dni.

We wrześniu 2003 r. dotychczasowi duszpasterze salezjańscy w katedrze przekazali świątynię i duszpasterstwo tamtejszemu biskupowi i klerowi diecezjalnemu. Proboszczem, na miejsce ks. Ignacego Ryndzionka, został ks. Jan Dąbal. Salezjanie zamieszkali w otwartym domu zakonnym w Odessie - w Salezjańskim Centrum Młodzieżowym im. św. Dominika Savio, przy ul. Malinowskiego $35 \mathrm{~A}^{32}$. Jego pierwszym dyrektorem został mianowany ks. Andrzej Baczyński, który przybył do Odessy w pierwszej połowie 2003 r. z Rzymu. Przy katedrze Wniebowzięcia biskup odesko-symferopolski, ks. Bronisław Bernacki, zorganizował Kurię Diecezjalną. Obecnie w Odessie funkcjonuje 5 parafii, w których pracuje 10 kapłanów, z biskupem diecezjalnym.

\section{Duszpasterstwo salezjanów na Ukrainie}

Od 1985 r. rządcą imperium radzieckiego był Michaił Gorbaczow. Religią „państwową” był nadal ateizm, ale za jego rządów narastało odrodzenie uczuć religijnych, w ścisłym związku z problemami narodowościowymi i społecznymi. $\mathrm{Na} 150$ mln obywateli republik radzieckich do religii przyznawało się ok. 130 mln. Po raz pierwszy w prasie radzieckiej („Komsomolska Prawda” z 10 XII 1985 r.) pojawił się artykuł, w którym autor E. Jewtuszenko stwierdzał, że społeczeństwo sowieckie składa się z ludzi wierzących i niewierzących, a do ateizmu nie wolno nikogo przymuszać. Wreszcie nominowany na stanowisko przewodniczącego Rady ds. Religii przy Radzie Najwyższej ZSRR Konstantin Charczew zaczął się odnosić przychylnie do petycji ludzi wierzących domagających się swoich praw do wolności wyznawania wiary ${ }^{33}$.

W 1988 r. odbyły się uroczystości Millenium Chrztu Rusi Kijowskiej. Uroczystości miały charakter kościelny i państwowy. Z tej okazji papież Jan

\footnotetext{
${ }^{32}$ Relacja ks. I. Ryndzionka z 9 IX 2003 r. - Odessa (zb. aut.).

${ }^{33}$ B. K u m o r, Historia Kościoła, cz. 8, Lublin 1996, s. 583-584.
} 
Paweł II skierował dwa listy apostolskie do Rosjan i Ukraińców - katolików. Dnia 1 XII 1989 r. odbyło się historyczne spotkanie w Watykanie Michaiła Gorbaczowa z Janem Pawłem II. Już wówczas postanowiono nawiązać stosunki dyplomatyczne. W następstwie tych wydarzeń i zmian otwarto w latach 1989-1990 nowe prawosławne Seminaria Duchowne, a w 1993 r. katolickie Seminarium Duchowne w Moskwie, przeniesione w 1996 r. do Sankt Petersburga ${ }^{34}$.

W wyniku „pierestrojki” Gorbaczowa zelżał ogólny klimat w Związku Sowieckim, skutkiem czego doszło do jego rozpadu, a poszczególne republiki kolejno ogłaszały niepodległość. W 1991 r. ogłosiła niepodległość Ukraina. Mimo że pozostało dotychczasowe komunistyczne prawodawstwo w stosunku do Kościoła katolickiego (Komitet Kościelny - „dwadcatki”, „sprawki”, rejestracja parafii), wierni mogą swobodnie wyznawać wiarę. Wielu salezjanów decydowało się wyjechać do pracy misyjnej na Wschód: na Białoruś, Litwę, do Rosji, na Ukrainę, do Kazachstanu, Gruzji i dalej.

Zanim zostało proklamowane państwo Ukrainy, tamtejsi katolicy stopniowo odzyskiwali zabrane im w latach komunizmu świątynie. Odczuwalny był wówczas brak duszpasterzy. Ci przyjeżdżali z zagranicy, głównie z Polski. W tej liczbie znaleźli się, obok księży zakonnych i diecezjalnych, również polscy salezjanie, którzy przejmowali stopniowo tamtejsze duszpasterstwo parafialne. Pierwsi salezjanie wyjeżdżający na Wschód, bo tak określano pracę w państwach byłych republik radzieckich, należeli do polskich prowincji, w których do tej pory pracowali. Z czasem ich liczba wzrastała, a salezjanie obejmowali parafie; należało tworzyć odpowiednie struktury lokalne i prowincjalne czyli administracji salezjańskiej na Wschodzie.

Tak doszło 8 XII 1993 r. do powstania Okręgu Wschodniego Niepokalanego Poczęcia NMP z siedzibą w Moskwie. Jego przełożonym w randze inspektora (prowincjała) został ks. Zdzisław Weder. Do Okręgu Wschodniego należały placówki salezjańskie z Rosji, Litwy, Białorusi, Ukrainy (obu obrządków: łacińskiego i bizantyjsko-ukraińskiego), Gruzji. Dnia 15 VIII 2005 r. domy salezjanów litewskich zostały przyłączone do Inspektorii Lombardzko-Emiliańskiej pw. św. Karola Boromeusza z siedzibą w Mediolanie, a domy współbraci obrządku ukraińsko-bizantyjskiego na Ukrainie także 15 VIII 2005 r. utworzyły Delegaturę Inspektorialną Ukrainy z siedzibą we Lwowie. Powyższe zmiany administracji salezjańskiej na Litwie i Ukrainie zostały dokonane decyzją Generała Zgromadzenia w Rzymie ${ }^{35}$. W obecnym zarządzie inspektora Okręgu Wschodniego w Moskwie pozostają placówki w Rosji, Białorusi, Ukrainy (obrządku łacińskiego) i Gruzji.

Parafia św. Mikołaja w Bóbrce. Najmniejsze miasto Ukrainy, najbiedniejszego powiatu województwa lwowskiego. W 1999 r. zamieszkiwało tam ok. 4 tysiące

${ }^{34}$ Tam mieściło się w historycznym budynku seminarium archidiecezji mohylowskiej.

${ }^{35}$ Dekret Przetożonego Generalnego o przytaczeniu domów salezjańskich na Litwie do Inspektorii Lombardzko-Emiliańskiej, w: Dokumenty Rady Generalnej, Kraków 2005 nr 389 Rok LXXXVI kwiecień-czerwiec 2005, s. 83-84, Dekret Przetożonego Generalnego o ustanowieniu Delegatury obrzadku bizantyjsko-ukraińskiego w Ukrainie, w: Dokumenty Rady Generalnej, Kraków 2005 nr 389 Rok LXXXVI kwiecień-czerwiec 2005, s. 81-82. 
mieszkańców, w tym: ok. 300 łacinników, tyleż samo prawosławnych, pozostali grekokatolicy.

Według tradycji fundatorem drewnianego kościoła w 1402 r. w Bóbrce był Zawisza Czarny. Odnowienia erekcji parafii dokonał w 1548 r. arcybiskup lwowski Piotr Strzechowski. Budowę murowanego kościoła ukończono w 1771 r. W latach 1914-1922 rozbudowano świątynię, dodając na patrona, obok św. Mikołaja - św. Annę. Po II wojnie światowej uniknięto zamknięcia kościoła ze strony władz radzieckich. Z posługą duszpasterską dojeżdżał tam z katedry we Lwowie ks. Konrad.

W latach 50. ubiegłego stulecia wrócił z więzienia ks. Janosz Rabar, hrabia, birytualista, główny jego obrządek grekokatolicki. Pochodził z Zakarpacia, Węgier z pochodzenia, który znał język polski. Znał go wcześniej proboszcz katedry lwowskiej o. Rafał Kiernicki, który zaproponował mu przyjazd do Lwowa na rozmowę. Wspólnie ustalili, że ks. Rabar zatai przed władzami, że jest kapłanem grekokatolickim ${ }^{36}$ i żonaty, a na tej podstawie poczynią obaj wspólne starania $\mathrm{u}$ władz wyznaniowych o rejestrację ks. Rabara z przeznaczeniem na proboszcza w Bóbrce. Rejestracja udała się, otrzymał „sprawkę” na proboszcza w Bóbrce. Zamieszkał u grekokatolickiej rodziny naprzeciw kościoła. Niestety, nieostrożność ze strony żony i dzieci mieszkających na Zakarpaciu, którzy przysłali mężowi i ojcu do Bóbrki życzenia imieninowe i świąteczne sprawiły, że KGB odkryło całą prawdę o nim. Na rozprawie otrzymał wyrok, jako karę za sprawowanie funkcji kapłańskich: 10 lat pracy w cegielni w Bóbrce. W konsekwencji kościół parafialny został zamknięty w 1962 r. Dokonano wówczas totalnej dewastacji jego wnętrza, gdy wyposażenie świątyni: ołtarze, ławki, obrazy rąbano i palono na środku kościoła i w szkolnej kotłowni. Parafianom udało się uratować nieliczne mniejsze przedmioty. W tym pomagał ówczesny kościelny. Tymczasem w kościele urządzono salę zabaw. W czasie sylwestrowej zabawy tanecznej u tańczącej dziewczyny zapaliły się włosy na głowie. Zostało to odczytane jako „kara” za profanację świątyni, a chętni do zabawy dyskotekowej w świętym miejscu zaniechali przychodzenia tam. Wówczas zdecydowano, że zabytkową budowlę przejmie miejscowa szkoła, z przeznaczeniem na salę gimnastyczną dla uczącej się młodzieży. Tymczasem ks. Rabar, po odbyciu kary 10 lat w cegielni, powrócił na Zakarpacie do rodziny. Zmarł na początku lat 90 . ubiegłego stulecia. Parafianie w Bóbrce wspominają go jako solidnego i uczciwego kapłana ${ }^{37}$.

Po zamknięciu kościoła parafialnego w Bóbrce wierni gromadzili się na nabożeństwa w kaplicy cmentarnej rodziny Czajkowskich ${ }^{38}$, których inicjatorem był Michał Tarnawski (1904-1995), miejscowy stolarz. Część wiernych obawiała się

${ }^{36}$ Z nakazu władz radzieckich w 1946 r. zwołany został synod Kościoła grekokatolickiego. Żaden z hierarchów nie poddał się presji władz, za co spotkały ich szykany i więzienia. Powołana została grupa inicjatywna z trzech księży, z których dwu wyświęcono na biskupów prawosławnych moskiewskich. Ci zwołali synod, na którym orzeczono przystąpienie grekokatolików co prawosławia, przez co nastąpiło administracyjne zlikwidowanie unitów.

${ }^{37}$ Relacja ks. Andrzeja Baczyńskiego z 20 I 2006 r. - Przemyślany (zb. aut.).

${ }^{38}$ Kaplica zbudowana około 1881 r. jako cmentarna kaplicy rodzinna. Wybudowana odmiennie jak kościoły czy cerkwie na terenie Galicji, które zazwyczaj usytuowane były ołtarzem na wschód. 
represji i była ostrożna co do uczestnictwa w nabożeństwach liturgicznych na cmentarzu, inni uczestniczyli. Władze takie praktyki tolerowały przeszło 20 lat. W niedziele i święta kościelne o godzinie, o której w katedrze lwowskiej były odprawiane np. nieszpory, nabożeństwa majowe i różańcowe, zgromadzeni na cmentarzu w Bóbrce wierni odprawiali paralelnie takie samo nabożeństwo. W przypadku pogrzebu należało uzyskać u władz pozwolenie na odprawienie katolickiego pogrzebu przez kapłana z katedry lwowskiej. Podobnie było z udzielaniem sakramentu chorych. Jednak jego udzielanie najczęściej traktowane było przez kapłana jako funkcja duszpasterska „prywatna”, a kapłani wówczas przybywali jakby w odwiedziny. Stąd pozwolenie władz w takich przypadkach nie było tak rygorystycznie przestrzegane, jeśli chodzi o parafian. Tak było m.in. z ks. Ludwikiem Kamilewskim, który udzielił sakramentu chorych na własną odpowiedzialność. Poinformowane władze wezwały go na przesłuchanie. Tłumaczył się u wyznaniowca. Zakończyło się pomyślnie ${ }^{39}$.

Kiedy przyszła „odwilż” w latach 80 . ubiegłego stulecia w byłych republikach radzieckich, doczekał się także Kościół na Ukrainie upragnionej wolności.

Ks. Ludwik Kamilewski, jako wikariusz katedry lwowskiej, „nakręcał” wiernych w Bóbrce, aby starali się o rejestrację wspólnoty parafialnej i odzyskanie kościoła. Na początek było 5 osób odważnych, na czele z entuzjastycznie nastawioną panią Eugenią Zastawną, która wbrew wszystkim gorliwym rozpoczęła w lipcu 1989 r. starania o odzyskanie kościoła. Wsparli ją miejscowi katolicy. W sierpniu tego roku przyszło stosowne pismo od władz i nastąpiło przekazanie kluczy do świątyni katolikom. Inauguracyjna Msza św. została odprawiona dnia 21 XII 1989 r. w IV niedzielę adwentu przez biskupa Mariana Jaworskiego z Lubaczowa, który poświęcił oddany kościół parafialny w Bóbrce. Mszę św. koncelebrowali tego dnia z biskupem duszpasterze lwowscy: ks. Ludwik Kamilewski i ks. Marian Buczek, obecnie sufragan lwowski ${ }^{40}$.

Pierwszy proboszczem w Bóbrce został mianowany ks. Ludwik Kamilewski, który dojeżdżał z Lwowa. Od maja 1990 r. do pomocy duszpasterskiej przyjeżdżał o. Stanisław Fudala, karmelita z Polski, który z polecenia przełożonych miał poczynić starania o odzyskanie klasztoru karmelitów we Lwowie (obecnie zajmują go studyci). Był on kierowany przez proboszcza katedry z posługą do Bóbrki, z dojazdem do miejscowości Kurowicze. Jak wielu innych zakonników, przyjechał i on na ziemię lwowską by pomagać w duszpasterstwie na miarę ówczesnych możliwości.

Kolejnymi proboszczami w Bóbrce byli salezjanie. Wikariusz z katedry lwow-

Kaplica Czajkowskich ołtarz ma ukierunkowany na zachód, co może sugerować o jej luterańskiej przeszłości. Михаило Русин, Храми Перемишлянщини, Перемишляни-Копула 2003, s. 8.

39 Ярополк Царик, Духовнісвятині Бібрики, Вібрка-Львів, s. 64; Relacja ks. Andrzeja Baczyńskiego z 20 II 2006 r.- Przemyślany (zb. aut.).

${ }^{40}$ Bp Jaworski jako administrator archidiecezji lwowskiej z siedzibą w Lubaczowie przyjeżdżał już od 7 listopada tego roku na tereny archidiecezji leżące w Ukraińskiej SRR. Z okazji takiego przyjazdu, w jedną niedzielę poświęcał nawet 3 kościoły odzyskane, sprawując w nich Eucharystię. 
skiej, ks. Andrzej Baczyński ${ }^{41}$, dojeżdżał we wtorki, piątki i niedziele z Lwowa do Bórski przez 5 lat, od 1991 do 14 IX 1995 r. Jednak na miejscu nie było stałego proboszcza. Pomagał mu wówczas w duszpasterstwie ks. Piotr Smolka z Przemyślan. W jesieni 1995 r. przyjechał do Lwowa były misjonarz salezjański z Zambii, ks. Piotr Malec. Wrócił z misji po 3-krotnej malarii i zatrzymał się tymczasowo u rodziny w Polsce. Odwiedził także rodzinne strony rodziców - Ziemię Lwowską. Wówczas ks. Baczyński zaproponował mu probostwo w Bóbrce. Przyjął ofertę i pracował tam ks. Malec kilka miesięcy. Po nim, od sierpnia 1996 r., proboszczem został ks. Marek Poniewierski. Ponieważ w tym roku zostało otwarte Wyższe Seminarium Duchowne Archidiecezji Lwowskiej w Brzuchowicach pod Lwowem (kurs propedeutyczny), ks. Poniewierski został mianowany, od listopada tego roku, przez abpa Jaworskiego prefektem alumnów. Zastąpił go w parafii Bóbrka ks. Stanisław Buchta, który w październiku 2005 r. złożył rezygnację z probostwa na ręce inspektora Okręgu Wschodniego, ks. Henryka Boguszewskiego. Na jego miejsce został mianowany ks. Edward Mackiewicz ${ }^{42}$.

${ }^{41}$ Ks. Baczyński, ur. 28 XII 1963 r. we Lwowie. Studia seminaryjne odbywał w Rydze w latach 1986-1991. W czasie studiów odbył w tamtejszych warunkach nowicjat salezjański. Święcenia kapłańskie przyjął 18 V 1991 r. z rąk abpa Mariana Jaworskiego we Lwowie. Po święceniach pracował jako wikariusz w katedrze 1991-1995, następnie jej proboszcz 1995-1998. W 1998 r. wyjechał na studia na salezjańskim Universita Pontificia Salesiana w Rzymie, ukończone doktoratem z prawa kanonicznego dnia 20 II 2003 r. W marcu tego roku przybył do Odessy na przełożonego wspólnoty Matki Bożej Wspomożenia Wiernych, przy ul. Malinowskiego 35 A. Pracował nadto w Trybunale Biskupiego Sądu w Odessie. Kierował organizowaniem od podstaw salezjańskiego Centrum Młodzieżowego i pomagał w duszpasterstwie przy kościele św. Piotra. Po śmierci ks. Tadeusza Hoppe (zm. 10 XI 2003 r.) przejął po nim funkcję proboszcza tej parafii, którą salezjanie, po odejściu z katedry, otrzymali na własność od miejscowego biskupa Bernackiego. Relacja ks. A. Baczyńskiego z 20 II 2006 r. - Przemyślany (zb. aut.).

${ }^{42}$ Ks. Mackiewicz, święcenia otrzymał 26 V 1981 r. w Lądzie. Od 1989 r. wyjeżdżał do pracy duszpasterskiej na Białoruś (Oszmiana, Żuprany) do pomocy ks. Zaniewskiemu. Pracował kolejno w Rosji i na Białorusi: wikariusz w parafii św. Klemensa w Saratowie (4 II - IX 1992), wikariusz parafii w dzielnicy Słobudka w Lidzie (połowa X 1992 - IX 1993), gdzie proboszczem był ks. Kazimierz Szoka, następnie podjął obowiązki proboszcza parafii pw. Ostatniej Wieczerzy w Rostowie nad Donem i parafii pw. MB Wniebowziętej w Nowoczerkasku w Rosji (XI 1993-10 IX 2002). Na tamtych terenach bardzo ruchliwe były sekty religijne niemieckie. Przeciwdziałając temu, administrator apostolski Rosji Europejskiej, ks. Tadeusz Kondrusiewicz skierował ks. Mackiewicza do pracy na terenach rosyjskich. W drodze z Polski, we wrześniu 2002 r., ks. Edwardowi odmówiono wjazdu do Rosji. Tym samym przestał być proboszczem w Rostowie. Zmuszony sytuacją przybył do Wilna, jednak kard. Audyrus Juzoas Bačkis nie wyraził zgody na jego pracę na Litwie. Skierował się do Korostyszewa na Ukrainie, gdzie pracował jako wikariusz parafii i administrator (prefekt) domu salezjańskiego. Na początku marca 2004 r. opuścił Ukrainę i przybył do Kowna (dzielnica Palemonas - kościół pw. MB Różańcowej) na Litwę. Tu u salezjanów litewskich podjął podobne obowiązki jak w Korostyszewie - administratora domu. Po wyłączeniu salezjańskich domów litewskich z Okręgu Wschodniego i przyłączeniu do Prowincji Mediolańskiej ks. Mackiewicz podjął urlop zdrowotny, z myślą o zaniechaniu pracy w Okręgu Wschodnim. We wrześniu 2005 r. na rekolekcjach w Przemyślanach k. Lwowa otrzymał nominację na wikariusza w Bóbrce, a dekretem z 3 XII 2005 r. został mianowany administratorem parafii Bóbrka. Relacja ks. Edwarda Mackiewicza z 20 II 2006 r. - Przemyślany (zb. aut.). 
Od momentu rejestracji parafii w Bóbrce w pracy duszpasterskiej pomagają Siostry Franciszkanki Rodziny Maryi, które na terenie parafii posiadają dom zakonny. Przed II wojną światową prowadziły w parafii szpital. Do Bóbrki przybyły w 1906 r. W bieżącym roku będą obchodzić jubileusz 100-lecia przybycia, z przerwą w latach 1943-1980 komunistycznych represji rządów radzieckich. Siostry prowadzą obecnie w parafii katechizację, pełnią funkcję zakrystianki, troszczą się o bieliznę i paramenty kościelne oraz prowadzą parafialne grupy młodzieżowe.

Duszpasterze z Bóbrki dojeżdżają także z posługą duszpasterską do kościoła św. Stanisława Biskupa i Męczennika w Dunajowie. Swiątynia zbudowana w latach osiemdziesiątych XV w., zniszczona przez Tatarów i gruntownie odbudowana sto lat później, jednonawowa, na planie krzyża, z kamienia i cegły. Obronny charakter świątyni potwierdzają otwory strzelnicze na wieży i pod dachem prezbiterium. Wnętrze zdobi malowidło L. Winterowskiego wykonane w czasie odnawiania kościoła w 1909 r. Msza św. sprawowana jest tam w niedziele i święta o godz. $12.30^{43}$.

Ciekawą i niespotykaną inicjatywę w Bóbrce podjął proboszcz ks. Stanisław Buchta w 2000 r. Dysponując odpowiednim zapleczem mieszkaniowym na wybudowanej plebanii, zorganizował dla 7 dziewcząt miejscowych całodobową opiekę: mieszkanie, wyżywienie, opiekę wychowawczą i odpowiedzialność za ich kształcenie. Z tej liczby piątka dziewcząt to rodzeństwo, a pozostałe dwie pochodzą z innych rodzin patologicznych. Rodzice ich zostali pozbawieni praw rodzicielskich. Opiekę kuratorską na plebanii z ramienia władz spełnia kompetentna wychowawczyni. Plebania katolicka zastąpiła im na pewien czas dom rodzinny. Po sześciu latach, kiedy najstarsza $\mathrm{z}$ grupy rodzeństwa uzyskała pełnoletność, miejscowe władze przydzieliły rodzeństwu mieszkanie, do którego będą mogły się przeprowadzić latem $2006 \mathrm{r}$. Pod opieką salezjanów pozostaną jeszcze dwie dziewczynki, które nadal nie mają własnego mieszkania. Na pewno nie zostaną one wyrzucone z plebanii bez opieki i dachu nad głową ${ }^{44}$.

Parafia Świętych Apostołów Piotra i Pawła w Przemyślanach. Pierwszą świątynią katolicką w Przemyślanach była kaplica ufundowana w 1642 r. przez Annę Krzelczycką Mrożkową. W 1665 r. wybudowany został kościół murowany dla potrzeb Zakonu Kaznodziejskiego (dominikanów), ufundowany przez księżnę Elżbietę Potocką. Podczas konsekracji w 1730 r. nadano mu tytuł Świętych Apostołów Piotra i Pawła. W 1939 r. świątynia parafialna została zamknięta przez sowietów. W niedługim czasie ponownie udostępniona wiernym, przez kilka lat spełniała przeznaczenie Domu Bożego. Przez 20 lat służbę w kościele pełnił ks. Piotr Stanaszek. On był również ostatnim proboszczem, do czasu definitywnego zamknięcia kościoła w 1946 r. przez władzę radziecką. Przez 46 lat świątynia była profanowana i dewastowana. Najpierw zlokalizowano w niej skład drewna, a w latach 70. ubiegłego stulecia uruchomiono tam fabrykę Modul, filia fabryki w Kijowie. Tak było do 1997 r. Dla potrzeb fabryki budowlę sakralną przedzie-

${ }^{43}$ J. T o k a r s k i, Ilustrowany przewodnik po zabytkach na Ukrainie, t. 1, Warszawa 2000, s. 37.

${ }^{44}$ Relacja ks. Stanisława Buchty z 3 VI 2004 r., ks. - Bóbrka (zb. aut.). 
lono, zalewając strop w nawie głównej, a na uzyskanym piętrze zwiększyła się powierzchnia przemysłowa dla produkcji.

Do dziś zachował się z świątyni parafialnej krzyż z głównego ołtarza, obecnie znajduje się w cerkwi greckokatolickiej. Proboszcz ks. Smolka zwracał się wielokrotnie z prośbą o jego zwrot ale bezskutecznie. Proponował także wykonanie dla obecnych jego posiadaczy nowego o takich samych parametrach, jednak bezskutecznie. $Z$ jednej strony brak dobrej woli, a z drugiej strony ogromna determinacja parafian rzymskokatolickich z Przemyślan, którzy pod tym krzyżem modlili się od dzieciństwa i do dzisiaj stanowi on dla nich nie tylko pamiątkę tamtych, jak wspominają, dobrych czasów. Ponadto zachowała się figura Chrystusa Zmartwychwstałego i 9 stacji Drogi Krzyżowej. Natomiast ołtarz boczny MB Częstochowskiej świątyni przemyślańskiej i dzwon „Zygmunt” jest do dziś w kościele Trójcy Przenajświętszej w Borszczowie (dek. Czortków).

Dnia 13 XII 1991 r. została zarejestrowana w Przemyślanach parafia rzymskokatolicka. Początki organizowania wspólnoty katolickiej i parafii spadł na barki wikariuszy katedry lwowskiej: ks. Ludwika Kamilewskiego i ks. Andrzeja Baczyńskiego. Oni niejako otwierali parafie i poszukiwali do nich stałych duszpasterzy.

Parafia katolicka w Przymyślanach zyskała rejestrację władz, ale kościół użytkowany był przez przedsiębiorstwa państwowe. Wierni i duszpasterze czynili usilne starania o odzyskanie go, ale mimo otrzymania stosownych pism od władz ministerialnych i wyznaniowych informujących o zwrocie świątyni, katolicy napotykali na przeszkody, okupione sporymi sumami. $Z$ tego powodu jeszcze przez 5 lat wierni zbierali się pod gołym niebem przy cmentarnej kaplicy na Mszę św. i nabożeństwa. Po przezwyciężeniu ogromnych trudności kościół został odzyskany dla parafii gdy proboszczem jej był i jest nadal ks. Piotr Smolka ${ }^{45}$.

Jak ks. Smolka trafił do Bóbrki? Inspektor Prowincji św. Jacka z siedzibą w Krakowie, ks. Piotr Biegus, poszukiwał współbrata w Polsce, który zdecydowałby się wyjechać na Ukrainę, do pomocy ks. Andrzejowi Baczyńskiemu. Zgłosił się ks. Smolka, pracujący wówczas na placówce i parafii salezjańskiej MB Wspomożenia Wiernych w Lublinie na Kalinowszczyźnie. Dnia 4 VIII 1993 r. wyjechał ks. Smolka, do Bóbrki najpierw na pomocnika ks. Baczyńskiego, następnie na proboszcza. Zamieszkał u Józefa i Stefanii Zakolaków. Pracował tam dwa lata. W 1995 r. przybył do Przemyślan na stałe, gdzie od początku pracy duszpasterskiej w Bóbrce dojeżdżał tam z pomocą w niedziele a także i w tygodniu. W związku z tymi przyjazdami organizował dla dzieci katechizację u pani Katarzyny Brody. Liturgię odprawiali na cmentarzu w prowizorycznej kaplicy już od 1 XI 1992 r. do 27 III 1997 r., mimo że już we wrześniu 1996 r. otrzymał ks. Smolka stosowny dokument, iż kościół jest oddany katolikom. Należało jednak spełnić pewne warunki, m.in. parafia czy salezjanie musieli zakupić piętrowy budynek wolno stojący w sąsiedztwie kościoła, wybudowany za czasów sowiec-

${ }^{45}$ Ks. Smolka, ur. 23 II 1953 r. w Zabrzu. Nowicjat ukończył złożeniem ślubów 22 VIII 1970 r. w Kopcu k. Częstochowy. Święcenia kapłańskie przyjął 21 VI 1980 r. w Krakowie. Pracuje na Ukrainie od 1993 r. L. K a 1 i ń s k i, Rodzina salezjańska w Polsce. Wykaz domów i osób, Warszawa 1988, s. 81, 106, 112, 117, 122, 127. 
kiech dla przedsiębiorstw produkujących w zabranym kościele. Wówczas generał Zgromadzenia Salezjańskiego, ks. Jan Vecchi w październiku 1996 r. zwizytował parafię salezjańską w Przemyślanach, a na jej zakończenie obiecał pomoc finansową na „konieczny” zakup sąsiedniej budowli.

Dnia 27 III 1997 r. katolicy weszli do górnego kościoła, po zakupieniu za wysoką sumę, budynku przykościelnego. Dnia 1 IV 1997 r. metropolita lwowski, kard. Marian Jaworski dokonał poświęcenia tej części kościoła. Funkcję proboszcza pełni ks. Piotr Smolka. Katolicy nie ustawali w staraniach o zwrot także dolnej części zajmowanego kościoła. Wreszcze udało się. Odchodzący dotychczasowi użytkownicy dokonali na pożegnanie ogromnego zniszczenia. Zrzucili strop żelbetowy na posadzkę kościoła, niszcząc ją w celowy i bezmyślny sposób.

Jak w każdej parafii salezjańskiej tak i w Przemyślanach duszpasterze okazują szczególną troskę o młodzież i starają się jej towarzyszyć w wyborach drogi życiowej. Prowadzą katechizację dzieci przedszkolnych i starszych. Przygotowują $\mathrm{z}$ nimi przedstawienia teatralne, m.in. bożonarodzeniowe Jasełka odgrywane w języku polskim i ukraińskim. Parafianie należą do Żywego Różańca. Dla dzieci i młodzieży organizowane są wyjazdy na kolonie, obozy ${ }^{46}$ i Savionalia ${ }^{47}$ do Krakowa.

W pracy duszpasterskiej jako wikariusze pracują w Przemyślanach: ks. Franciszek Rosłan ${ }^{48}$ i ks. Jan Niemiec ${ }^{49}$ oraz ks. Edward Zajączkowski, który fak-

${ }^{46}$ Między innymi byli w Celestynowie i Białymstoku.

${ }^{47} \mathrm{~W}$ połowie lat 80 . ubiegłego stulecia krakowska Inspektoria św. Jacka zainicjowała przy Wyższym Seminarium Duchownym Towarzystwa Salezjańskiego w Krakowie (na Łosiówce) przy ul. Tynieckiej 39 zgrupowanie młodzieżowych grup i drużyn sportowych, z salezjańskich placówek i parafii inspektorii krakowskiej. Na program takiego zgrupowania składają się rozgrywki sportowe w poszczególnych dyscyplinach, inaugurowane Mszą św. i tematycznym programem liturgicznokatechetycznym i formacyjnym. Odbywa się ono po dziś dzień w dniach 1-3 maja każdego roku, przed liturgiczną uroczystością patrona młodzieży św. Dominika Savio (5 maja), stąd nazwa Savionalia.

${ }^{48}$ Ks. Rosłan, salezjanin, ur. 7 VI 1933 r. w miejscowości Podleńce. Nowicjat ukończył złożeniem ślubów 2 VIII 1954 r. w Czerwińsku. Święcenia kapłańskie przyjął 1 VI 1965 r. w Lądzie n. Wartą. Po święceniach zgłaszał przełożonym pragnienie wyjazdu do pracy duszpasterskiej na Wschód. Od 1989 r. wyjeżdżał „turystycznie” na zaproszenie do pomocy duszpasterskiej na Białoruś do Porozowa (za Wołkowyskiem), Solecznik Wielkich (Litewska SRR) oraz Oszmiany (Białoruska SRR). Po wyjeździe na stałe na Białoruś w 1991 r. pracował w: Oszmianie (1.5 roku), Krupowie po śmierci ks. Wacława Stefanowicza (4 lata), Wornianach (1 rok). Od 1997 r. pracuje jako wikariusz parafii w Przemyślanach. K a 1 i ń s k i, Rodzina salezjańska w Polsce, s. 235, 283, 290, 295, 298; Relacja ks. F. Rosłana z 29 VIII 2005 r., 20 II 2006 r.- Przemyślany (zb. aut.).

${ }^{49}$ Ks. Niemiec, ur. 18 V 1950 r. w Niedźwiedzy, nowicjat 1982/1983 w Czerwińsku, święcenia kapłańskie w 1991 r. Do pracy na Wschodzie wyjechał w 1994 r. Pracował na Białorusi w Oszmianie (1994-1995). Wyrzucony stamtąd przez władze wyznaniowe przyjechał na Ukrainę - do Korostyszewa (1995-1996). Następnie powrócił na Białoruś, do parafii Boruny (IV 1996-XII 1999). W latach 1999-2004 pracował w Polsce. Po raz trzeci wyjechał na Białoruś do Borowlan (20042005). Od 2005 r. pracuje w parafii Przemyślany. Relacja ks. Jana Niemca z 20 II 2006 r.- Przemyślany (zb. aut.). 
tycznie od dwóch lat mieszka i pracuje w Bóbrce, jednak przynależy do wspólnoty w Przemyślanach.

Duszpasterze z Przemyślan dojeżdżają także do Świrskich Chlebowic, gdzie wierni gromadzili się w drewnianej kaplicy. Proboszcz, ks. Smolka rozpoczął tam budowę kaplicy murowanej pw. św. Antoniego. Jej poświęcenia dokonał dnia 4 IX 2004 r. metropolita lwowski, kard. Marian Jaworski. Mimo że tamtejsza społeczność katolicka jest liczebnie najmniejsza w porównaniu do grekokatolików i prawosławnych, są jednak dumni z poświęconej świątyni św. Antoniego, gdzie gromadzą się nie tylko na sprawowanie liturgii. Odpowiednie zaplecze służy młodzieży na spotkania religijne, kulturalne i nawet rozrywkowe. Daje to możliwość do integracji tamtejszej młodzieży nie tylko katolickiej.

Ponadto salezjanie z Przemyślan obsługują kościół w Pohorylcach, oddalonych o $7 \mathrm{~km}$ i kaplicę w Plecenicach oddalonych $15 \mathrm{~km}$.

Parafia Narodzenia NMP w Korostyszewie. Parafia w diecezji kijowsko-żytomierskiej, gdzie jednym z pierwszych duszpasterzy, po odzyskaniu kościoła przez katolików 29 VI 1991 r., był ks. Jan Purwiński, który dojeżdżał z Żytomierza. Następnie już jako biskup diecezjalny w Żytomierzu zaproponował salezjanom przejęcie tamtejszego duszpasterstwa. Na zaproszenie biskupa pojechał do Korostyszewa na Ukrainie pełniący obowiązki prowincjała na Wschodzie, ks. Zdzisław Weder z ks. Antonim Murzińskim ${ }^{50}$. Ks. Murziński pozostał tam tymczasowo (od kwietnia do września 1991 r.) mieszkając w Żytomierzu. Dojeżdżał na początek do 5 wiosek (objazd $400 \mathrm{~km}$ ). Dnia 19 IX $1991 \mathrm{r}$. został mianowany tam proboszczem i rozpoczął remont kościoła. Parafia korostyszewska liczyła wówczas 300 wiernych. Zdarzały się niedziele, że ks. Antoni odprawiał nawet 5 Mszy św.

W 1995 r. biskup parafię korostyszewską przekazał salezjanom. Obecnie liczy ok. 2000 wiernych. Pierwszym przełożonym domu salezjańskiego został ks. Antoni Murziński, tamtejszy proboszcz. Dnia 10 X 1995 r. został przeniesiony do pracy w Seminarium Duchownym w Sankt Petersburgu. Na jego miejsce przybył jako dyrektor i proboszcz ks. Jan Niemiec, wyrzucony przez władze Białorusi

${ }^{50}$ Ks. Murziński, ur. 15 III 1944 w miejscowości Milewskie. Nowicjat odbył w 1961/1962 w Czerwińsku, święcenia kapłańskie 6 X 1972 r. w Rumii. W grudniu 1990 r. wyjechał z Debrzna (prowincja pilska) na Wschód. Wspólnie z ks. Stanisławem Ługowskim i ks. Janem Hibner mieli przygotowywać się do funkcji kapelanów Sióstr Matki Teresy z Kalkuty w ich domach na terenie Rosji (Petersburg, Moskwa, Nowosybirsk). Tymczasem w listopadzie 1990 r. nuncjuszem został abp Francesco Colasuono, a księża, którzy z nim przybyli, objęli planowane dla trzech salezjanów funkcje kapelanów. Plan dla nich przepadł. Wówczas inspektor polskiej Prowincji św. Wojciecha w Pile, ks. Stanisław Skopiak, załatwił ks. Antoniemu zaproszenie na Białoruś, z przeznaczeniem do Zdzięcioła (diec. grodzieńska). Nim doszło do wyjazdu, tamta placówka była już obsadzona. Przełożony prowincji jednak polecił pojechać na Białoruś, celem rozpatrzenia się na miejscu. Ks. Antoni zatrzymał się trzy miesiące w Oszmianie, gdzie proboszczem był ks. Antoni Rafałko. Po miesiącu wracał do Polski i wyjeżdżał ponownie na kolejne zaproszenie. Pracując miesiąc w Żupranach (diec. grodzieńska) przygotowywał się do wyjazdu na Ukrainę oraz towarzyszył przełożonemu prowincjalnemu, ks. Wederowi w jego podróżach po salezjańskich placówkach na Wschodzie. Na Ukrainie rozpoczął pracę od Korostyszewa. Relacja ks. Antoniego Murzińskiego z 20 II 2006 r. - Przemyślany (zb. aut.). 
z parafii w Oszmianie. Tu pracował do kwietnia 1996 r., po czym powrócił na Białoruś do parafii w Borunach, w diecezji grodzieńskiej ${ }^{51}$.

W lipcu 1994 r. wikariuszem w Korostyszewie został mianowany ks. Cezary Czerwiński ${ }^{52}$. Wyświęcony na kapłana wraz z swoim współbratem i kolegą, ks. Józefem Żołnowskim ${ }^{53}$ w Żytomierzu. Ci dwaj neoprezbiterzy salezjańscy byli pierwszymi kapłanami wyświęconymi w tym mieście po przeszło 80 latach. W 1996 r. ks. Czerwiński przejął obowiązki przełożonego domu i proboszcza parafii korostyszewskiej. Od 2003 r. proboszczem został ks. Vitalij Krzyvicki, a ks. Cezary Czerwiński pozostał nadal przełożonym tamtejszej wspólnoty salezjańskiej.

Tamtejsi salezjanie (czterech) dojeżdżają do 13 duszpasterskich punktów dojazdowych, w tym do dwu miast (Brusiłów i Józefówka). Przy parafii funkcjonuje Oratorium młodzieżowe. Są plany aby w najbliższym czasie otworzyć Centrum Młodzieżowe ${ }^{54}$.

W tamtejszej parafii pracował od 1998 r. ks. Józef Żołnowski, będąc zarazem proboszczem w Brusiłowie. Po święceniach w 1991 r. pracował u swego proboszcza w Nowogrodzie Wołyńskim i budował kościół w miejscowym Rycholsku. Obecnie jest chory i pozostaje w Korostyszewie.

Od 18 XII 2005 r. pracuje w tamtejszej parafii jako wikariusz ks. Józef Bogusz $^{55}$.

${ }^{51}$ Relacja ks. Jana Niemca z 20 II 2006 r. - Przemyślany (zb. aut.).

${ }^{52}$ Ks. Czerwiński, ur. w 1960 r. w miejscowości Tucza, kosiatyńskiego rejonu, winnickiej obłasti (Ukraina). Studia seminaryjne odbył w Seminarium w Rydze w latach 1986-1991. Nowicjat odbył w czasie studiów seminaryjnych. Święcenia kapłańskie otrzymał w 1991 r. w Żytomierzu z rąk bpa Jana Purwińsiego, tamtejszego ordynariusza. Pracował jako wikariusz miejscowego proboszcza oraz na placówkach diecezji kijowsko-żytomierskiej: w Berdyczowie (3 lata), następnie Korosteń, Olewsk, Ługiny, Owrucz, Nowobiałokorowicze, Rokitno, Jamielianówka, Rużyn, Cudno. Od połowy 1994 r. pracuje w Korostyszewie. Relacja ks. Cezarego Czerwińskiego z 20 II 2006 r. - Przemyślany (zb. aut.).

${ }^{53}$ Ks. Żołnowski, ur. w 1964 r. w miejscowości Abramek, rejon Nowograd Wołyński, obłasti żytomierskiej. Studia seminaryjne odbył w latach 1987-1991 w Rydze, łącznie z odbyciem nowicjatu salezjańskiego. Święcenia kapłańskie w 1991 r. w Żytomierzu. Po święceniach pracuje duszpastersko na Ukrainie. Relacja ks. Antoniego Murzińskiego z 20 II 2006 r. - Przemyślany (zb. aut.).

${ }^{54}$ Relacja ks. Vitalija Krzyvickiego z 20 II 2006 r. - Przemyślany (zb. aut.).

${ }^{55}$ Ks. Bogusz, ur. 13 IV 1949 r. w Brudzewicach. Nowicjat salezjański odbył w Czerwińsku 1973/1974, seminaryjne studia filozoficzne w Lądzie n. Wartą 1974-1976. W październiku 1976 r. wyjechał na misje do Brazylii, teologię studiował w Sao Paulo na Lapa 1978-1981, święcenia kapłańskie otrzymał dnia 29 VI 1982 w Studzianne-Poświętne z rąk bpa St. Stefanka. W latach 19811992 pracował na placówkach salezjańskich w Brazylii. Pod koniec sierpnia 1992 r. powrócił do Polski. Pracując przez rok w Suwałkach wyjeżdżał do pracy w Oszmianie na Białorusi (1 miesiąc). Na początku września 1993 r. wyjechał na stałe na Białoruś i pracował kolejno w: Lidzie (2 IX 1993-25 VIII 1996), Krupowie k. Lidy (25 VIII 1996-20 XI 1997: proboszcz od 29 XI 1996), Bidrowce (do 20 XI 1997), następnie wyjechał do Rosji i pracował w: Moskwie-Oktjabrskij jako administrator nowicjatu (10 XII 1997-23 VI 2003), Samarze (23 VI 2003-16 XII 2005) i ostatnio od 17 XII 2005 r. pracuje w Korostyszewie na Ukrainie. Ks. Józef Bogusz, Curriculum vitae. 


\section{a) Delegatura inspektorialna Ukrainy}

Zamysł utworzenia bizantyjsko-ukraińskiej gałęzi w Zgromadzeniu Salezjańskim powstał w 1930 r. Na prośbę nuncjusza apostolskiego w Polsce abpa Franciszka Marmaggi Przełożony Generalny Zgromadzenia, ks. Filip Rinaldi, pozytywnie ustosunkował się do tej propozycji. W 1932 r. z upoważnienia i pod patronatem metropolity lwowskiego Andrzeja Szeptyckiego, przy poparciu biskupa przemyskiego Jozafata Kocyłowskiego udała się pierwsza grupa ukraińskich młodzieńców i kandydatów do zgromadzenia na salezjańską formację do Włoch. W późniejszych latach: 1937, 1938, 1939 udały się kolejne trzy. Kandydaci ci, późniejsi salezjanie, byli narodowości ukraińskiej, nie posiadali jednak własnej państwowości, a w Ukraińskiej SRR religia katolicka doznawała wielorakich represji, stąd ci salezjanie pracowali wśród wiernych swojej narodowości w społecznościach rozsianych na różnych kontynentach, głównie w obu Amerykach; Północnej i Południowej. Dopiero w 1991 r. mogli powrócić do proklamowanego państwa Ukrainy. W wyniku politycznych zmian i rozpadu Związku Sowieckiego władze ukraińskie zezwoliły na sprawowanie kultu w świątyni wotywnej na Górnym Łyczakowie we Lwowie. Świątynię przejęła Cerkiew prawosławna. Po skutecznych zabiegach kościół przejęli w końcu salezjanie obrządku bizantyjskoukraińskiego. Rozpoczęli od zorganizowania tam ośrodka duszpasterskiego. Dziś funkcjonuje tam parafia i ośrodek młodzieżowy z odpowiednim zapleczem.

Obecnie salezjanie obrządku bizantyjsko-ukraińskiego posiadają dwie placówki: we Lwowie i w Użgorodzie. Pierwsza mieści się na Górnym Łyczakowie, przy ul. Łyczakowskiej, w dawnym kościele pw. Matki Bożej Ostrobramskiej, wybudowanym w latach trzydziestych ubiegłego stulecia, staraniem metropolity lwowskiego obrządku łacińskiego. Oprócz pracy duszpasterskiej w tamtejszym kościele salezjanie gromadzą tam dzieci i młodzież w Oratorium młodzieżowym, gdzie mają odpowiednie warunki i możliwości do rozrywki, formacji duchowej i modlitwy. W okresie wakacyjnym organizują dla młodzieży obozy letnie, nazywane „Wesołe wakacje”. Ponadto powołali do życia Młodzieżowe Centrum Kształcenia oraz prywatne Liceum im. błog. Klimentego Szeptyckiego. Dla szerszego kręgu odbiorców organizują wszelkiego rodzaju inicjatywy religijno-wychowawcze dla dzieci i młodzieży miasta Lwowa.

We wrześniu 2005 r. otwarli kolejną placówkę w mieście Użgorodzie, gdzie inicjują dzieło św. Jana Bosko.

Wymienione dwie placówki przynależą do utworzonej w 2005 r. delegatury inspektorialnej Ukrainy pw. Maryi Wspomożenia Wiernych dla współbraci obrządku bizantyjsko-ukraińskiego z siedzibą we Lwowie.

\section{b) „Świetlany Dom” dla dzieci ulicy}

Geneza „Świetlanego Domu” sięga przełomu lat 1988/1989, kiedy to w charytatywnej Fundacji Pomocy Społecznej im. Doktora Gaaza w Odessie rozpoczął działać Aleksander Czumakow z nieliczną grupą pomocników. Dzięki nim został 
uruchomiony niepaństwowy telefon zaufania dla dzieci i młodzieży, nazywany w Odessie „telefonem zrozumienia”. Młodzi zgłaszali swoje problemy pod wskazany telefon i poszukiwali różnorakiej pomocy oraz rozwiązania swoich problemów życiowych. Równolegle z zainicjowaniem „telefonu zrozumienia” tworzono formację „MIU” - Miłosierdzie Młodości. Przy tej formacji po raz pierwszy na Ukrainie skupiała się grupa wolontariuszy, głównie studenci wyższych uczelni Odessy, którzy spontanicznie chcieli nieść pomoc bezdomnym „dzieciom ulicy" ${ }^{\prime 5}$.

W miesiącach letnich (maj i czerwiec) 1989 r. zgłaszały się pod wskazany numer telefoniczny bezdomne dzieci i młodzież, prosząc głównie o żywność. W związku z powyższym służby „MIU” poszukiwały współpracy z profesjonalnymi pedagogami, którzy połączyli się w stowarzyszenie o nazwie „Skrzyżowanie”. Zgłaszające się sieroty otrzymywały krótkoterminowe schronienie i pomoc socjalną w suterenowych pomieszczeniach D. P. Rżepiszewskiego, mieszczących się przy ul. Bazarnej (Kirowa) 2/1 w Odessie, a ta instytucja dobroczynna otrzymała nazwę „Przytułek”. Każdego miesiąca znajdowało tam schronienie 6-10 bezdomnych małolatów, a środki finansowe na tę działalność zdobywano od miejscowego społeczeństwa, firm biznesowych i zachodnich sponsorów (np. kanadyjscy mennonici). Była to działalność niepaństwowa oparta wyłącznie na ofiarności darczyńców. Ponadto „Przytułek” gromadził informacje o dzieciach maltretowanych przez rodziców, doznających upokorzeń w internatach, sprawcach i ofiarach ulicznych rozbojów, młodych kryminalistach, narkomanach itp. Tego rodzaju działalność niewielkiego „Przytułku” zaczęła napawać trwogą resortowych urzędników państwowych, którzy jednogłośnie twierdzili, że „w ich kraju dzieci ze złamanym losem nie ma". Cyfry i fakty chociażby w samej Odessie przeczyły temu stwierdzeniu. Statystyki dzieci bezdomnych, zawszonych, chuligańskich, okradających kogo tylko się dało i wchodzących na drogę przestępczą wciąż rosły, a „Przytułek” w piwnicy przy ul. Bazarnej nie był w stanie nie tylko ich pomieścić ale także zaspokoić ich podstawowych potrzeb. Tymczasem miejskie służby sanitarne stawiały bardzo poważne zastrzeżenia. Tylko w przeciągu trzech miesięcy (I-III) 1990 r. władze dzielnicy miejskiej Żówtrzewa trzykrotnie zabraniały pracy $\mathrm{z}$ dziećmi $\mathrm{w}$ tych pomieszczeniach. Czteropokojowe pomieszczenie piwniczne, pozbawione odpowiednich sanitariatów, często zalewane odpływami kanalizacyjnymi nie mogło służyć nawet jako tymczasowe mieszkanie dla dzieci - orzekały tamtejsze służby sanitarne, a miejscowe władze miejskie nie proponowały zastępczego lokum. Taka „wojna” o przetrwanie schroniska trwała aż do stycznia 1995 r, kiedy to decyzją urzędników resortu zdrowia jedyne schronisko dziecięce o nazwie „Przytułek”przy ul. Bazarnej 2/1, działające w opar-

${ }^{56}$ Afisz reklamujący „telefon zrozumienia” informował, że Laboratorium „Miłosierdzie Młodości” Fundacji Pomocy Społecznej im. Doktora Gaaza pomaga w sytuacjach kiedy: Ciebie nie rozumieją; Dojżewa skandal; Męczy samotność; Zagubiłeś się i nie wiesz jak żyć. Dzwoń pod numer ... W godzinach od 18.00-8.00 dnia następnego. Grupa „Miłosierdzie Młodości” postara się pomóc. Grupa „Miłosierdzie Młodości” postara się pomóc także rodzicom, złagodzić stosunki i relacje ze swoimi dziećmi. Świetlany Dom. Niedokończona historia 1989-1995, http://svetly-dom. org.ru/house/history_001.html 
ciu o Społeczno-Pedagogiczne Stowarzyszenie (SPO) - „Siedem krasnoludków”, którego szefem był D. P. Rżepiszewski, został zamknięty ${ }^{57}$.

Postawę organów państwowych w podjęciu tej decyzji nie można osądzać jako wyrachowanie urzędnicze. Przewodniczący Urzędu Miasta ds. Rodziny, Młodzieży, Kultury Fizycznej i Sportu, panowie Rentow i Czernow, przychylnie odnosili się do działalności Rżepiszewskiego, a nawet sympatyzowali z nim. I chociaż kryzys finansowy Urzędu ds. Rodziny nie pozwalał im dotować finansowo przewodniczącego stowarzyszenia „Siedem krasnoludków” - Rżepiszewskiego, wsparcie moralne i przyjacielskie urzędników administracji miejskiej w odniesieniu do jego działalności też miało swoje znaczenie. Można także zrozumieć postawę władz oświatowych - miejskiego Kuratorium Oświaty. W zespole Rżepiszewskiego rzeczywiście nie było fachowców do pracy opiekuńczo-wychowawczej z dziećmi. Dlatego zamknięcie instytucji dobroczynnej „Przytułek”, w styczniu 1995 r., było logiczne i przewidziane. Patrząc jednak z drugiej strony, wraz z tą decyzją nie znikły problemy bezdomnych dzieci w Odessie. Niestety, jedyny $\mathrm{w}$ mieście, a nawet $\mathrm{w}$ całym centralnym i południowo-wschodnim regionie Ukrainy, społeczny sierociniec dla dzieci został zamknięty wtedy, gdy w państwie ukraińskim lawinowo rosną statystyki dzieci niczyich i pozostawionych własnemu losowi.

Jak wythumaczyć to dzieciom zmarzniętym, bezradnym, zawszonym, że: „W pomieszczeniu brak warunków na zamieszkanie, które odpowiadają normom sanitarno-higienicznym"? Jak wytłumaczyć owiniętym w łachmany, koczującym w lochach, w opuszczonych wagonach, na strychach, w piwnicach..., że w państwowych przepisach zawarte są pewne normy, które dla pozoru są demonstrowane przed społecznością światową. Normy, o realizację których na co dzień nikt się nie troszczy. Urzędnicy proponowali obklejać opuszczone przez dzieci speluny i sutereny kartkami z wydrukowanymi na nich odpowiednimi przepisami, żeby przynajmniej ci, którzy umieją czytać, dowiedzieli się jakie życie państwo uważa dla nich za normę do przyjęcia. Niech w śmierdzących, ciemnych oborach i piwnicach, odpędzając od siebie szczury, czytają normy, niech czytają...

Dla starców i emerytów, którzy przynosili tym dzieciom pożywienie, tłumaczenie, dlaczego państwo nie zapewnia tym dzieciom minimum socjalnego, jest zbędne. Oni doskonale znają swoje państwo, którego przeszłość sami budowali. I tylko kilku dziennikarzy, którzy nie stracili ludzkiej wrażliwości i pozostali wierni normom sumienia, alarmowali w prasie i telewizji, a społeczeństwo miasta jakby budziło się i dostrzegało poważny problem dzieci niczyich.

Na przełomie marca i kwietnia (1995 r.) terenowi inspektorzy udostępnili urzędnikom informację o „dziecięcych piwnicach”. Wydawało się, że skończą się dyskusje na temat, że „Przytułek” nie jest potrzebny. I oto szczęście. W końcu

${ }^{57}$ Decyzja władz była zasadna. Pomieszczenia „Przytułku” były w ruinie, opiekę nad dziećmi sprawowali nie profesjonaliści, brak było jakiejkolwiek opieki medycznej. Życie „Przytułku” podtrzymywane było dzięki szefowi organizacji „Siedem krasnoludków” Rżepiszewskiemu, którego kondycja zdrowotna i duchowa z dnia na dzień gasła, a z upływem czasu w murach schroniska dla dzieci panował coraz większy chaos i niepewność. Świetlany Dom. Czy pamiętasz jak wszystko się zaczęło, http://svetly-dom.org.ru/house/streetchildren_002.html 
został otwarty Obwodowy Przytułek - ,ppierwszy w Odessie”. Jednak to szczęście było wątpliwe. Ten przytułek okazał się być częścią Dziecinnego Obwodowego Przytułku Rozdzielczego. Atmosferę w takim Przytułku Rozdzielczym najlepiej przedstawi list jednego z jego mieszkańców do szefa „Świetlanego Domu”, diak. Aleksandra Czumakowa: ,W maju tego roku zabrali mnie do tego przytułku. Byłem tam 30 dni. Potem mnie wezwał naczelnik i powiedział: idź gdzie chcesz, my ciebie zwalniamy. Idź w Odessę i jeśli cię złapiemy, to będzie gorzej. Ojcze Aleksandrze, ponieważ nie mam gdzie iść, przyjmijcie mnie do „Przytułku” dla sierot, ponieważ mnie wypuścili z Przytułku Rozdzielczego".

Pozbawione opieki i pomocy dzieci bezdomne gromadziły się po rowach kanalizacyjnych, w traktach ciepłowniczych, podziemnych przejściach (katakumbach), pośród ruin wyłączonych z eksploatacji budynków, dokonując aktów przestępczych. Katastrofalna sytuacja tych dzieci wymagała natychmiastowego działania i takie zostało zainicjowane.

Dnia 28 X 1995 r. przybył do Odessy, po odbyciu studiów seminaryjnych w Wyższym Seminarium Duchownym Towarzystwa Salezjańskiego w Krakowie, diak. Aleksander Czumakow, salezjanin ${ }^{58}$. Dnia 28 XI 1995 r. SpołecznoPedagogiczne Stowarzyszenie (SPO), ,Siedem krasnoludków” pana D. P. Rżepiszewskiego rozpoczęło program „Ekologia dzieciństwa” autorstwa diakona Czumakowa, odtąd nazywanego przez dzieci „ojcem”. Wówczas nastąpiło wręczenie kluczy od byłego „Przytułku” autorowi programu „Ekologia dzieciństwa”. Tak ,ojciec” Czumakow przejął „Przytułek” przy ul. Bazarnej 2/1 z rąk Rżepiszewskiego.

Na bazie pomieszczeń zamkniętego w styczniu 1995 r. „Przytułku” rozpoczął Czumakow pracę nad realizacją własnego programu. Na początek należało przygotować odpowiednią grupę wolontariatu. Pracę z dziećmi oparł na systemie wychowawczym Zgromadzenia Salezjańskiego, wypracowanym przez założyciela Zgromadzenia - św. Jana Bosko (1815-1888), określanego jako salezjański system wychowawczy, zwany prewencyjnym. W oparciu o tę metodę wychowaw-

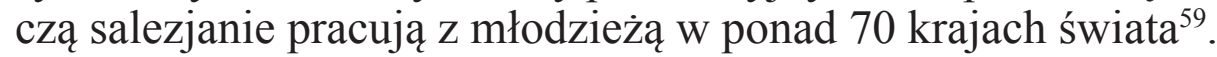

Tymczasem zbliżała się zima, a oficjalny zakaz działalności „Przytułku” przy ul. Bazarnej ciągle obowiązywał. Przełom nastąpił w wigilię Bożego Narodzenia, gdy drużyna wolontariatu z Aleksandrem Czumakowem zasiadła do wieczerzy przy śpiewie kolęd. Według starej tradycji, zanim zasiądzie się w ten wieczór do stołu, należy z modlitwą zapalić trzy świece: przed świętym obrazem, na stole i na parapecie okna. W ten wieczór wigilijny winno być także wolne miejsce dla

${ }^{58}$ Diak. Czumakow, autor programu „Ekologia dzieciństwa”, pochodzący z Odessy. W 1980 r. ukończył studia filologiczne na uniwersytecie odeskim, pedagog. Od 18 lat niezmienny opiekun dzieci w obozie pionierskim „Albatros”. Pracował jako wykładowca w szkole średniej nr $80 \mathrm{i} \mathrm{nr} 28$ w mieście. Następnie pracował jako psycholog, powołując laboratorium, Miłosierdzie Młodzieżowe” - pierwszy w Odessie niepaństwowy telefon zaufania dla dzieci i młodzieży przy fundacji Gaaza. W latach 1990-1995 Aleksander odbywał studia seminaryjne w Wyższym Seminarium Duchownym Towarzystwa Salezjańskiego w Krakowie. W międzyczasie odbył specjalistyczną formację psychologiczno-pedagogiczną. Powrócił do Odessy jako diakon.

${ }^{59}$ Świetlany Dom. Salezjanie świętego Jana Bosko, htp://www.sdbua.net/attivita/compi/vk2005 
przybysza, który w każdej chwili może się zjawić. Stało się tak, że w momencie śpiewania kolęd i zapalania świecy na oknie, drzwi piwnicy uchyliły się i na próg ostrożnie wstąpiło pięcioro zmarzniętych i wygłodniałych maleństw odzianych w łachmany. Pojawienie się ich odczytane zostało przez zebranych jako „znak z góry”. Były „Przytułek” został reanimowany w ten wieczór na przekór wszelkim zakazom urzędowym i funkcjonował mimo wielu przeciwności. Następujące miesiące były prawdziwą próbą sił o jego przetrwanie. Przetrwał wyłącznie dzięki ofiarności społeczeństwa, które zaangażowało się w tę pomoc. Przychodziły kobiety, także w wieku podeszłym ${ }^{60}$, które przynosiły chleb, mleko i odzież dla dzieci. Mieszkańcy „Przytułku”, często zbuntowani na świat, który je odrzucił, nauczeni kraść, napadać na słabszych, powoli odkrywali dla siebie świat ludzkiej dobroci. Doznający pomocy często zadawali personelowi pytanie: dlaczego ludzie przynoszą wiktuały i odzież dla nich, mimo że ich nie znają. Powoli zaczęli mówić „dziękuję” i uśmiechać się z wdzięcznością. Mimo że ten proces nie postępował szybko, ich życie, głęboko zranione przez los, powoli napełniało się nadzieją, która zadomowiała się $\mathrm{w}$ ich duszach, a to przecież nie mało ${ }^{61}$.

Po Odessie rozeszła się wieść, że ksiądz z trzema studentami zbiera w suterenie bezdomne dzieci. Interesowali się tą inicjatywą zarówno jej zwolennicy i przyjaciele jak i przeciwnicy. Ponownie uaktywniła się czujność ukraińskiego Sanepidu. Jednak i tym razem okazała się ich bezradność, gdy biedne dzieci zostały okryte sutanną ich „duchowego ojca”, który i tym razem okazał się nieugiętym w obronie dzieci.

Jednostkowa pomoc dobroczyńców nie rozwiązywała podstaw funkcjonowania tej instytucji charytatywnej. Kolejna pomoc przyszła nieoczekiwanie. Główny rabin miasta Odessy, Iszaji Gisser, w czasie spaceru po mieście ze swoimi uczniami zawitał do piwnicy gdzie mieścił się przytułek dziecięcy. Ktoś poinformował go, że tam może spotkać dawnego przyjaciela z dzieciństwa - Saszę Czumakowa w otoczeniu biednych dzieci. Przyszedł, rozejrzał się, nic nie powiedziawszy wyszedł. Wrócił za godzinę z parą dziesiątków skrzyń humanitarnej pomocy. „To tak na początek" - powiedział.

Borykający się z niedostatkiem materialnym „Przytułek”, „wówczas jedyny tego rodzaju na Ukrainie", stanął nieco na nogi. W ślad za rabinem Gisserem przyszedł jeszcze inny dobrodziej, który zapewnił przytułkowi ochronę do dnia dzisiejszego. Był to Włodzimierz Iljicz Kucenko, podpułkownik policji na emeryturze i prezes fundacji „Obrona” do walki ze zorganizowaną przestępczością. Z pomocą pośpieszyli dziennikarze: Aleksander Wałczek i Natalia Simisinowa. Ich reportaże o nielegalnym „Przytułku” i sytuacji „dzieci ulicy” miasta Odessy poinformowały opinię publiczną o wielkiej wadze problemu, jakim są bezdomne dzieci w Odessie ${ }^{62}$.

${ }^{60}$ Trudno zapomnieć staruszkę, która przyniosła do „Przytułku” niewielką reklamówkę kaszy i dwie cebule. Podzieliła się nie tym co jej zbywała lecz tym co posiadała, jak ewangeliczna wdowa.

${ }^{61}$ Świetlany Dom. Niedokończona historia 1995-1996, http:/svetly-dom.org.ru/house/history_ 003.html.

${ }^{62}$ Świetlany Dom. Niedokończona historia 1996, http:/svetly-dom.org.ru/house/history_004. 
Do „Przytułku” przy ul. Bazarnej dzieci nikt nie przywozi, one lgną tu same. Chociaż pomieszczenia nie odpowiadają „normom” i nie najlepiej z wyżywieniem. Mówią jego mieszkańcy, że tutaj uważają ich za ludzi, mimo że „Przytułek” był wciąż zagrożony.

W kwietniu 1996 r. rozpoczął się burzliwy rozwój nie istniejącego oficjalnie „Przytułku”, dzięki jego przyjaciołom i środkom masowego przekazu. Sierociniec przeżywał wówczas szereg najazdów urzędników likwidacyjnych a cała akcja zmierzała do wyprowadzenia dzieci i opieczętowania zajmowanych przez nie pomieszczeń. Personel kierowniczy pozostawał nieugięty. W tej sytuacji Rada Miasta Odessy ogłosiła zawieszenie broni. Obrońcą sierot okazał się zastępca burmistrza Igor Nikołajewicz Słoboda.

Dla rozwiązania problemów finansowych nielegalnego schroniska o nazwie „Przytułek” została powołana dobroczynna Fundacja „Świetlisty Dom”. Założycielem fundacji byli: ojciec Aleksander Czumakow, prezes Fundacji „Zachyst” - W. I. Kucenko, obwodowy rabin - Iszaji Gisser, prezes miejskiej fundacji pomocy społecznej - A. Kruppnik, generalny dyrektor Ukraińskiego Centrum Kultury „Ukraina” - A. P. Kryglikkowa, dyrektor Instytutu Badawczego Kuratorium i Rehabilitacji - prof. D. P. Babow, dyrektor organizacji i budowy Liceum im. Diagielewa - T. M. Pussowa.

Dnia 24 V 1996 statut Fundacji ,Świetlisty Dom” został złożony do rejestracji w Radzie Miejskiej. Dzięki wsparciu wspomnianego już zastępcy burmistrza - Igora Nikołajewa została przeprowadzona legalizacja tej działalności dobroczynnej a dotychczasowy „Przytułek” otrzymał nazwę „Świetlany Dom”, którego urzędowa rejestracja miała miejsce $30 \mathrm{~V} 1996 \mathrm{r}$. Od 6 czerwca tego roku w pomieszczeniach byłego „Przytułku” przy ul. Bazarnej 2/1 rozpoczęto konieczne prace remontowe. Do tych prac zgłaszali się wolontariusze, którzy w ten sposób pragnęli wesprzeć to dzieło.

Odtąd rozpoczęło się normalne życie. Dziennikarze telewizyjni i prasowi nagłaśniali temat bezdomnych dzieci, a ten stawał się modny, chociaż z tego powodu dzieciom nie żyło się lepiej. Tylko w 1996 r. „Świetlany Dom” zorganizował 7 letnich obozów pozamiejskich, m.in. w miasteczkach namiotowych: w Chadżibejewskim Limanie, Jużnom Bugie i Kinburskoj Kosie. Kolonia letnia dzieci odeskich została zakończona wspinaczką na szczyt góry Chowerły w dniu Przemienienia Pańskiego, w 5-lecie niezależności Ukrainy. Tę wspinaczkę pobłogosławił metropolita kijowsko-wyżhorodzki cerkwi greckokatolickiej - Lubomyr Huzar $^{63}$.

W lipcu 1996 r. na mocy decyzji władz miejskich „Świetlanemu Domowi” przekazano pomieszczenia przy ul. Bazarnaja (Kiryła) 2/1 oraz zasygnalizowano wówczas o konieczności przyznania wolno stojącego domu na otwarcie schroniska.

W sierpniu 1996 r. „Świetlany Dom” w Odessie odwiedził przełożony generalny Zgromadzenia Salezjańskiego z Rzymu, ks. Jan Vecchi, wraz z przełożonym html.

${ }^{63}$ Świetlany dom. Niedokończona historia 1996, http:/svetly-dom.org.ru/house/history_004. html. 
Okręgu Wschodniego, ks. Zdzisławem Wederem z Moskwy oraz delegatem przełożonego generalnego dla krajów Europy Środkowo-Wschodniej, ks. Augustynem Dziędzielem z Rzymu. Mieszkało w nim wówczas prawie 60 dzieci.

We wrześniu 1996 r. mieszkańcy „Świetlanego Domu” rozpoczęli naukę według własnego programu „likwidacja analfabetów”. Dnia 24 XII 1996 r., dzięki zabiegom wspomnianego już zastępcy burmistrza odeskiego Igora Słobody, do dyspozycji „Swietlanego Domu” przekazano znajdujący się po sąsiedzku budynek byłego przedszkola $\mathrm{nr} 55^{64}$. Wieczerza wigilijna tego roku odbyła się już w nowym domu, który od dawna czekał na dzieci.

Lista darczyńców i dobrodziejów dzieci odeskich jest długa. W 1997 r. pośpieszył z pomocą dyrektor bazaru „Północnego” Marurenko Władimir Iwanowicz. Dzięki jego pomocy sieroty otrzymują cotygodniową pomoc dobroczynną, dzięki której spożywają posiłki 5 razy dziennie.

Dyrektor korporacji „Sojuz” - Siergiej Czaplik co miesięcznie finansował wypłaty dla 12 pracowników „Świetlanego Domu”. Niestety, ta pomoc skończyła się w lipcu 1998 r. w związku z likwidacją korporacji, a problem pensji dla pracowników istnieje do dnia dzisiejszego. Zimą tego roku od siarczystych mrozów ratowano ponad 80 dzieci. $Z$ powodu braku pomieszczeń zorganizowano sypialnie w salach szkolnych. Współpraca personelu z mediami przyczyniła się do pozytywnej oceny tej działalności przez miejscowe społeczeństwo.

W pierwszym półroczu 1997 r. „Świetlany Dom” odwiedzili przedstawiciele UNICEF $^{65}$ - Kaunter Parta i z Korpusu Pokoju. Pozytywnie ocenili dotychczasową działalność, ale pomocy żadnej nie przysłali. W tym roku poważną pomoc okazali mieszkańcy miasta Landsmeyer w Holandii i Regensburga w Niemczech. Z nieocenioną pomocą pośpieszyli nauczyciele szkół miejskich, którzy jako wolontariusze wspomagają edukację dzieci. W dniach od 1-7 VI 1997 r. zorganizowano tydzień obrony dzieci. Środki na przeprowadzenie tej akcji zostały przyznane przez fundusz „Odrodzenie" ${ }^{\prime 66}$.

Odeski półlegalny sierociniec przy ul. Bazarnej odwiedził dnia 16 VI $1997 \mathrm{r}$. katolicki arcybiskup Nowosybirska i apostolski wikariusz Syberii - Józef Wert, który zwiedzał Odessę z grupą amerykańskich Niemców odeskiego pochodzenia, którzy niegdyś emigrowali z południa Ukrainy ${ }^{67}$. Od tego czasu odwiedzający pozostali wiernymi dobrodziejami dzieci. W czasie wizyty arcybiskup poinformował, że w Nowosybirsku jest 5 rejonowych przytułków dla dzieci, a budowa szóstego - dwupiętrowego miejskiego przytułku katolickiego jest na ukoń-

${ }^{64} \mathrm{~W}$ tym domu urodził się poeta rosyjski Walenty Katajew i jego brat.

${ }^{65}$ UNICEF (ang. United Nationes Internationales Children's Emergency Fund, od 1953 r. United Nationes Children's Fund, Fundusz Narodów Zjednoczonych Pomocy Dzieciom), organizacja międzynarodowa powołana w 1946 r. przez Zgromadzenie Ogólne ONZ, w celu podnoszenia na świecie stanu zdrowotności, wyżywienia i warunków życiowych dzieci.

${ }^{66}$ Świetlany Dom. Niedokończona historia 1997, http:/svetly-dom.org.ru/house/history_005. html.

${ }^{67}$ Rodzina arcybiskupa także wyjechała do Kazachstanu z Odessy w latach trzydziestych ubiegłego stulecia. 
czeniu $^{68}$. Rada Miasta Nowosybirska opłaca 102 etaty pracowników i personelu przytułków dziecięcych w tym mieście. A w Moskwie, informował arcybiskup, funkcjonują sierocińce wyłącznie dla dziewcząt - 13. Mer Moskwy w programie telewizyjnym poinformował, że problem dzieci „bezdolnych” jest priorytetem dla Urzędu Miasta i jego budżetu ${ }^{69}$.

Latem 1997 r. zorganizowano dla dzieci 6 letnich obozów pozamiejskich. Do końca lata tego roku zwiększyła się także liczba mieszkańców schroniska - przeszło 100 dzieci. We wrześniu 1997 r. prezes „Świetlanego Domu”, ojciec Aleksander Czumakow otrzymał od władz miasta Odessy propozycję objęcia dyrektorstwa $\mathrm{w}$ miejskim internacie $\mathrm{nr} 4$ dla sierot i dzieci pozbawionych opieki rodzicielskiej. W ten sposób podjęto próbę połączenia internatu i „Świetlanego Domu", na bazie tego ostatniego. Ta inicjatywa jednak okazała się nieprawidłowa i nie powiodła się.

W pierwszej połowie 1998 r. „Świetlany Dom” stracił wielu przyjaciót70. Najbardziej dotkliwą stratą był wyjazd z kraju rabina Iszaji Gissera.

W połowie maja 1998 r. grupa dziennikarzy na czele z Olgą Herasiumiuk (Kompania Telewizyjna 1+1) nakręciła film telewizyjny o „Świetlanym Domie”. Film uzyskał wysokie notowania na konkursach i festiwalach filmowych.

Tymczasem dnia 1 VI tego roku (Dzień Dziecka) w „Świetlanym Domie” rozpoczęto kontrole przeprowadzane przez szereg komisji złożonych z urzędników odpowiednich wydziałów Urzędu Miasta ${ }^{71}$. Przed komisjami zostało postawione zadanie: udowodnić niezdolność organizacji społecznych w rozwiązywaniu problemów „,bezdolnych” (bez doli, nieszczęśliwych) dzieci oraz sporządzenie protokołu pokontrolnego, na mocy którego „Świetlany Dom” miał być podporządkowany administracji państwowej. Na szczęście normy prawne w tej dziedzinie okazały się tak niespójne i zagmatwane, że wspólny najazd urzędników, po miesiącu prac, okazał się bezcelowy, a cała sprawa pozostawiła po sobie spustoszenie i żal w sercach i umysłach, zarówno mieszkańców, jak i personelu ${ }^{72}$.

W lipcu i sierpniu 1998 r. w czasie seminarium zorganizowanego przez Ukraiński Uniwersytet Katolicki św. Klemensa w Rzymie, prezes „Świetlanego Domu" ojciec Czumakow spotkał się na audiencji z papieżem Janem Pawłem II. Wówczas okazało się, że papież wiedział o funkcjonowaniu w Odessie przytułku dla bezdomnych dzieci pod nazwą „Świetlany Dom”’3. Na pożegnanie Jan Paweł

\footnotetext{
${ }^{68}$ Jego budowę i wyposażenie finansuje Caritas niemieckiego miasta Fryburga.

${ }^{69}$ Świetlany Dom. Czy pamiętasz jak wszystko się zaczęło?, http:/svetly-dom.org.ru/house/ streetchildren.html

${ }^{70}$ Zniknął i w czasie kampanii wyborczej Igor Słoboda, szef oddziału prawniczego Urzędu Miasta Sergiej Warłamow, w czerwcu 1998 r. przestała działać korporacja „Sojuz”.

${ }^{71} \mathrm{~W}$ dniach 1-10 VI 1998 r. na zlecenie pełniącego obowiązki prezydenta miasta kontrolowały komisje z następujących wydziałów Urzędu Miasta: oświaty, młodzieży i sportu, ochrony zdrowia, kultury, opieki nad dziećmi niepełnoletnimi, gospodarki komunalnej.

${ }^{72}$ Świetlany Dom. Niedokończona historia 1998, http:/svetly-dom.org.ru/house/history_006. html.

${ }^{73}$ Najprawdopodobniej Ojciec Święty dowiedział się o przytułku w Odessie słuchając kilku transmisji Radia Watykańskiego.
} 
II pobłogosławił jego mieszkańcom i dwukrotnie powtórzył: „wytrzymać wszystko, mocno stać”. Kiedy nad „Świetlanym Domem” rozpętała się burza, przypominane słowa papieża powstrzymywały od ostatecznej rozpaczy ${ }^{74}$.

W sierpniu 1998 r. podczas kampanii wyborczej na mera miasta, jeden z kandydatów - Borys Borysiewicz Wichrow zorganizował maraton dobroczynny, który pozwolił uregulować schronisku długi za opłaty komunalne. Na kilka dni przed wyborami Wichrow wycofał swą kandydaturę i został mianowany prezesem Obwodowego Sądu Arbitrażowego. Pozostał przyjacielem dzieci i dobrodziejem „Świetlanego Domu” aż do ostatniego dnia życia. Dnia 24 V 1999 r. został zabity wraz z dyrektorem kampanii telewizyjnej AMT - Anatolijem Bondarem.

Od września tego roku nawiedziły dom kolejne inspekcje ${ }^{75}$. Jako ich efekt, w czasie przeprowadzania szeroko zakrojonej akcji „dary ziemi dzieciom Świetlanego Domu", ukazało sięrozporządzenie prezydenta miasta R. B. Bodełowa (nr 145-01), na mocy którego od 14 X 1998 r. działalność „Świetlanego Domu” faktycznie została zawieszona. To zarządzenie wywołało powszechny społeczny rezonans w mieście, obwodzie, kraju i za granicą. Nie sposób przytoczyć wszystkich, którzy wystąpili w obronie „Swietlanego Domu”. Na skutek powszechnego oburzenia społecznego dnia 6 listopada tego roku prezydent Bodełow wycofał rozporządzenie z 14 października. Straty moralne, które ponieśli dzieci, personel i współpracownicy sierocińca przez decyzję kasacyjną, były ogromne.

Poczynając od 23 XI 1998 r. „Świetlany Dom” został poddany kolejnym inspekcjom $^{76}$. I tak komisja KRU miała za zadanie: „sprawdzenie przestrzegania ustawodawstwa walutowego w czasie realizacji transakcji eksportowej i importowej” w sierocińcu. W grudniu tego roku, na skutek skargi „o niedotrzymanie norm obowiązującego ustawodawstwa przez Fundację Świetlany Dom" miały miejsce kolejne kontrole działalności schroniska ${ }^{77}$. Równolegle z tą lustracją zostały poddane szczegółowej kontroli osoby i organizacje, które dotychczas świadczyły pomoc materialną dla „Świetlanego Domu"78.

Od początku lutego 2006 r. Radca Generalny Towarzystwa Salezjańskiego, ks. Albert Van Hecke, przeprowadzał wizytację nadzwyczajną polskiej Inspektorii św. Jacka. W trakcie wizytacji, na zebraniu współbraci w Lublinie przy ul. Kalinowszczyzna 3 z księdzem wizytatorem, tamtejsi salezjanie zadali wizytatorowi pytanie na temat pracy diak. Aleksandra Czumakowa w Odessie. Przedstawił html.

${ }^{74}$ Świetlany Dom. Niedokończona historia 1998, http:/svetly-dom.org.ru/house/history_006.

${ }^{75}$ M.in. kontrolowali: zastępca prezydenta miasta - W. W. Popkow (2 razy), szef Komisji ds. Niepełnoletnich - A. W. Jsnyj (2 razy), kierownik Zarządu Oświaty - T. G. Urodowa, komisja Zarządu Ochrony Zdrowia (5 członków) na czele z kierownikiem - W .L. Kochanem.

${ }^{76}$ Przeprowadziła je prokuratura Żowtnewej dzielnicy Odessy, Komisja ds. Nieletnich, KRU (ukraińska NIK) obwodu odeskiego, zarząd Opieki Społecznej.

${ }_{77}$ M.in.służby Zarządu Obwodowego ds. Rodziny i Młodzieży i prokuratura dzielnicy Żówtnewej miasta Odessy, która przeprowadziła lustrację wraz z ekspertyzami prac remontowych przeprowadzonych latem 1996 r. Sprawdzone protokoły i dokumentacja pozostały bez zastrzeżeń.

${ }^{78}$ Świetlany Dom. Niedokończona historia 1998, http:/svetly-dom.org.ru/house/history_006. html. 
wówczas swoje spostrzeżenia poczynione w czasie wizytowania domów należących do Okręgu Wschodniego, w tym i w Odessie. Relacjonował, że jest to forma pracy z dziećmi bezdomnymi, która odbiega od naszych wyobrażeń i standardów. Ci wychowankowie wspinają się na przykład na drzewa w błyskawicznym tempie i przemieszczają się swobodnie po gałęziach, co obserwatora nie tylko zadziwia ale powoduje strach o ich bezpieczeństwo. Pod opieką ojca Aleksandra są dzieci, które w dotychczasowym swoim życiu nie mieszkały w mieszkaniu czy domu, nie tylko rodzinnym, ale w ogóle. Żyły dotychczas w dostępnych miejscach i spelunach poza domem. Współpraca między personelem nie jest łatwa, zważywszy przeszłość wychowanków i ich poziom intelektualny, duchowy i kondycję zdrowotną. Mimo tych wszystkich „niedoskonałości” i „trudności” w naszym rozumieniu, jakie można zauważyć w funkcjonowaniu „Świetlanego Domu”, ks. radca deklarował, że na możliwe sposoby będzie nadal pomagał diak. Aleksandrowi, mimo że na co dzień jego związek ze Zgromadzeniem czy odeską wspólnotą zakonną jest dość luźny. Pomaga biednym dzieciom i to jest najważniejsze ${ }^{79}$.

\section{Formacja i kształcenie kandydatów z Ukrainy do Zgromadzenia}

Od początku lat dziewięćdziesiątych ubiegłego stulecia polskie prowincje salezjańskie podjęły trud kształcenia i formacji do kapłaństwa kandydatów do zgromadzenia z ówczesnych republik radzieckich. W nowicjatach salezjańskich w Czerwińsku i Kopcu kandydaci z Ukrainy odbywali formację początkową, a w Seminariach Duchownych w Krakowie, Lądzie i Łodzi studiują do dziś klerycy obrządku łacińskiego i bizantyjsko-ukraińskiego z Ukrainy, którzy po święceniach pracują w tamtejszym duszpasterstwie i za granicą.

Po odbyciu odpowiedniej formacji zakonno-kapłańskiej i ukończeniu studiów seminaryjnych przyjmowali święcenia kapłańskie. Do nich należą: diak. Aleksander Czumakow (diakonat w 1984 obrz. biz.-ukr.), ks. Vitalis Krzyvicki (wyśw. w 1997), ks. Nuckowski Michał (1999), ks. Marian Kuc (2001). ks. Edward Zajączkowski (2002), ks. Samojłow Aleksander (2004), ks. Mylon Taras (2005 obrz. ukr.-biz.), ks. Czaban Michał (obrz. ukr.-biz.), ks. Palij Andrian (obrz. ukr.-biz.). W sumie 5 współbraci obrządku łacińskiego i 4 bizantyjsko-ukraińskiego, którzy w Polsce przygotowani zostali duchowo i intelektualnie do kapłaństwa i życia w Zgromadzeniu.

${ }^{79}$ Relacja ks. Alberta Van Hecke z 4 II 2006 r.- Lublin (zb. aut.). 


\title{
INCIDENZA DELL'ATTIVITÀ PASTORALE DEI SALESIANI NELLA CHIESA CATTOLICA IN UCRAINA
}

\author{
Riassunto
}

Nell'Ucraina, proclamata come Stato nel 1991, gli inizi del lavoro pastorale dei salesiani risalgono all'anno 1904. Dal punto di vista storico la parrocchia di Daszawa, situata vicino alla città di Stryj, nell'arcidiocesi di Leopoli, fu la terza presenza salesiana nei territori polacchi all'epoca occupati dalle potenze straniere.

La case salesiane (chiamate opere) erette nell'arcidiocesi di Leopoli (Daszawa - parrocchia, Leopoli-Łyczaków - attività pastorale, Leopoli - Opera Fondazione Abrahamowiczów, Drohowyże - Opera Fondazione del conte Stanisław Skarbek, Brodki - in stato di organizzazione) appartennero all'Ispettoria San Giacinto, con la sede a Cracovia, fino all'anno 1939. Dopo lo spostamento dei confini nell'Est della Polonia, avvenuto nel 1945, i salesiani persero nell'Est le loro undici opere, sorte prima del secondo conflitto mondiale; esse facevano parte dell'Ispettoria San Giacinto e dell'Ispettoria Santo Stanislao Kostka. La maggiore perdita di opere, cioè nel numero di cinque, avvenne nell'Ucraina Occidentale, incorporata nel 1939 alla Repubblica Socialista dell'Ucraina Sovietica. Ivi si verificò il più drammatico processo d'espatrio dei polacchi nel territorio della Repubblica Popolare Polacca. Da questo momento fino all'anno 1958 i salesiani non furono presenti nella Repubblica Sovietica dell'Ucraina. Alla fine di quest'anno il salesiano polacco don Tadeusz Hoppe lasciò la località di Ławaryszek, vicino a Vilnius, per spostarsi ad Odessa; ivi egli operò come pastore nella chiesa di San Pietro e, inoltre, estese la sua attività pastorale nelle quattro limitrofe regioni, fino alla sua morte (10 XI 2003). Durante il regime comunista vi arrivavano i singoli sacerdoti su "invito", tra cui anche salesiani, al fine di celebrare, sporadicamente e di nascosto, la sacra liturgia e d'impartire i sacri sacramenti ai fedeli.

Solo con lo sfacelo dell'Unione Sovietica e la proclamazione, nel 1991, dello Stato Ucraino la popolazione cattolica ritrovò la possibilità di ritornare alla prassi religiosa regolare. Anche se la chiesa cattolica finora non è riconosciuta dallo Stato, i cattolici tuttavia possono registrare le singole comunità parrocchiali e celebrare la liturgia nei loro tempi. Attualmente i salesiani di rito romano lavorano nelle quattro parrocchie e nelle loro filiali (Bóbrka, Korostyczew, Odessa, Przemyślany) e hanno un Centro Giovanile ad Odessa. Queste presenze salesiane appartengono alla cosiddetta Circoscrizione Speciale Europa Est Immacolata Concezione di Maria, eretta nel 1993, con la sede a Mosca. Inoltre i salesiani di rito bizantino-ucraino hanno due presenze a carattere pastorale, cioè a Leopoli e ad Użhorodzie. Queste costituiscono una Delegazione per l'Ucraina Maria Ausiliatrice, fondata nel 2005, con la sede a Leopoli.

Vale ricordare qui ancora un lavoro originale che compie il diacono Aleksander Czumakow nella forma di un orfanotrofio, chiamato „Świetlany Dom” (Casa Luminosa) per i ragazzi di strada: una realtà nata nel 1989. È una istituzione non governativa che realizza la sua missione grazie alle libere offerte della popolazione.

Le ispettorie polacche si sono assunte, dalla seconda metà degli anni ottanta del secolo scorso, la responsabilità per la formazione e lo studio dei candidati alla Società Salesiana provenienti dai territori delle ex repubbliche sovietiche, compreso quella dell'Ucraina. 